\title{
THE SEC'S RULE 10b-6: PRESERVING A COMPETITIVE MARKET DURING DISTRIBUTIONS
}

The recent Georgia-Pacific litigation serves to reiterate the broad question posed by the Special Study of the Securities Markets concerning the precise limits of the Securities and Exchange Commission's proscription of bidding and purchasing by interested persons during the course of a distribution. While the SEC has affirmed the need for clarification of some applications of the protean regulation, no definitive analysis has been forthcoming. In an attempt to ascertain the current view of the Commission with respect to enforcement of the prohibition and to isolate the more troublesome issues raised by the rule, this comment examines the background of the promulgation of rule 10b-6 as well as its major administrative and judicial interpretations.

$\mathrm{T}$ HE Securities Act of $1933^{1}$ and the Securities Exchange Act of $1934^{2}$ were both motivated to a large extent by a desire to prevent investors' losses due to market manipulations. ${ }^{3}$ The foundation upon which a regulatory framework was to be constructed lay in section 10 (b) of the 1934 Act. ${ }^{4}$ Through this provision, Congress has directed the Securities and Exchange Commission to prescribe such antimanipulation rules and regulations as are "necessary or appropriate in the public interest or for the protection of investors." Pursuant to this authorization, the Commission in 1955 promulgated rule $10 \mathrm{~b}-6,{ }^{6}$ which, with specified exemptions, proscribes bidding and

\footnotetext{
148 Stat. 74, as amended, I5 U.S.C. $\$ \S 77 a-a a$ (1964).

248 Stat. 881, as amended, 15 U.S.C. $\$ \S 78 \mathrm{a}-\mathrm{jj}$ (1964).

3 In his message to Congress calling for federal regulation of securities exchanges, President Roosevelt objected to "pool[s] of individuals or corporations with large resources . .. which sought by manipulation to raise or depress market quotations ...." H.R. REP. No. 1383, 73d Cong., 2d Sess. 1 (1934). Similarly, the Senate Report on the proposed Securities Exchange Act noted that "several devices are employed for the purpose of artificially raising or depressing security prices. Those which appear to serve no legitimate function are specifically prohibited." S. REP. No. 792, 73d Cong., 2d Sess. 7 (1934). See also Staff of Senate Comm. on Banking and Currency, 73d CONG., 2d SESS., Report Relative to Stock Exchange Regulation 13-16 (Comm. Print 1934). See generally 3 Loss, SecurtTIES Regulation 1529-40 (2d ed. 1961) [hereinafter cited as Loss]; Berle, Liability for Stock Market Manipulation, 31 CoLUM. L. REv. 264 (1931); Berle, Stock Market Manipulation, 38 Colum. L. REv. 393 (1938); Moore \& Wiseman, Market Manipulation and the Exchange Act, 2 U. CHI. L. REv. 46 (1934).

* Securities Exchange Act of $1934 \S 10$ (b), 48 Stat. 891, 15 U.S.C. $\$ 78 j$ (b) (1964).

I Ibid.

${ }^{\circ}$ I7 C.F.R. $\$ 240.10 \mathrm{~b}-6$ (1964, Supp. 1966) reads as follows:

" (a) It shall constitute a 'manipulative or deceptive device or contrivance' as used in section $10(\mathrm{~b})$ of the act for any person,
} 
(I) who is an underwriter or prospective underwriter in a particular distribution of securities, or

(2) who is the issuer or other person on whose behalf such a distribution is being made, or

(3) who is a broker, dealer, or other person who has agreed to participate or is participating in such a distribution, directly or indirectly, by the use of any means or instrumentahity of interstate commerce, or of the mails, or of any facility of any national securities exchange, either alone or with one or more other persons, to bid for or purchase for any account in which he has a beneficial interest, any security which is the subject of such distribution, or any security of the same class and series, or any right to purchase any such security, or to attempt to induce any person to purchase any such security or right, until after he has completed his participation in such distribution: Provided, however, That this section shall not prohibit (i) trans. actions in connection with the distribution effected otherwise than on a securities exchange with the issuer or other person or persons on whose behalf such distribution is being made or among underwriters, prospective underwriters or other persons who have agreed to participate or are participating in such distribution; (ii) unsolicited privately negotiated purchases, each involving a substantial amount of such security, effected neither on a securities exchange nor from or through a broker or dealer; or (iii) purchases by an issuer effected more than forty days after the commencement of the distribution for the purpose of satisfying a sinking fund or similar obligation to which it is subject; or (iv) odd-lot transactions (and the off-setting round-lot transactions hereinafter referred to) by a person registered as an odd-lot dealer in sucl security on a national securities exchange who offsets such odd-lot transactions in such security by round-lot transactions as promptly as possible; or (v) brokerage transactions not involving solicitation of the customer's order; or (vi) offers to sell or the solicitation of offers to buy the securities being distributed (including securities or rights acquired in stabilizing) or securities or rights offered as principal by the person making such offer to sell or solicitation; or (vii) the exercise of any right or conversion privilege to acquire any security; or (viii) stabilizing transactions not in violation of $\$ 240.10 \mathrm{~b}-7$; or (ix) bids for or purchases of rights not in violation of $\$ 240.10 \mathrm{~b}-8$; or $(x)$ transactions effected on a national securities exchange in accordance with the provisions of a plan filed by such exchange under $\$ 240.10 \mathrm{~b}-2$ (d) and declared effective by the Commission; or (xi) purchases or bids by an underwriter, prospective underwriter or dealer otherwise than on a securities exchange, 10 or more business days prior to the proposed com. mencement of such distribution (or 5 or more business days in the case of unsolicited purchases), if none of such purchases or bids are for the purpose of creating actual, or apparent, active trading in or raising the price of such security. In the case of securities offered pursuant to an effective registration statement under the Securities Act of 1933 the distribution sball not be deemed to commence for purposes of this subdivision prior to the effective date of the registration statement.

" (b) The distribution of a security (1) which is immediately exchangeable for or convertible into another security, or (2) which entitles the holder thereof immediately to acquire another security, shall be decmed to include a distribution of such other security within the meaning of this section.

"(c) The following shall be applicable for the purposes of this section.

(1) The term 'underwriter' means a person who has agreed with an issuer or other person on whose behalf a distribution is to be made (i) to purchase securities for distribution or (ii) to distribute securities for or on behalf of such issuer or other person or (iii) to manage or supervise a distribution of securities for or on behalf of such issuer or other person.

(2) The term 'prospective underwriter' means a person (i) who has agreed to submit or has submitted a bid to become an underwriter of securities as to which the issuer, or other person on whose behalf the distribution is to be made, has issued a public invitation for bids, or (ii) who has reached an understanding, with the issuer or other person on whose behalf a distribution is to be made, that he will become an under- 
purchasing during the course of a distribution by an underwriter, issuer, or other person participating in the offering. Because this rule is so closely related to the other SEC provisions directed against manipulative market transactions, many activities which violate its terms also fall within the prohibition of these other regulations. ${ }^{7}$ Yet by focusing on acquisitions during distributions, rule 10b-6 gains independent significance and becomes particularly relevant to corporate financing. In an attempt to ascertain the impact of this rule upon securities marketing methods, this comment will trace the development of rule $10 \mathrm{~b}-6$, outline its operation with a particular inquiry into its application in the recent Georgia-Pacific ${ }^{8}$ litigation, and evaluate the rule's significance as an antimanipulation regulation.

Pre-10b-6 regulation of market manipulation. Pre-1955 interpretations of the antimanipulation provisions of the 1933 and 1934 Acts

writer, whether or not the terms and conditions of the underwriting have been agreed upon.

(3) A person shall be deemed to have completed his participation in a particular distribution as follows: (i) The issuer or other person on whose behalf such distribution is being made, when such distribution is completed; (ii) an underwriter, when he has distributed his participation, including all other securities of the same class acquired in connection with the distribution, and any stabilization arrangements and trading restrictions with respect to such distribution to which he is a party have been terminated; (iii) any other person, when he has distributed his participation. A person, including an underwriter or dealer, shall be deemed for purposes of this subparagraph to have distributed securities acquired by him for investment.

"(e) The provisions of this rule shall not apply to any distribution of securities by an issuer to its employees, or to employees of its subsidiaries, or to a trustee or other person acquiring such securities for the account of such employees, pursuant to (l) a stock option plan involving only 'qualified stock options,' or qualifying as an 'employee stock purchase plan' as those terms are defined in sections 422 and 423 of the Internal Revenue Code of 1954, as amended, or 'restricted stock options' as defined in section 424 (b) of the Internal Revenue Code of 1954, as amended: provided however, that for the purposes of this paragraph an option which meets all of the conditions of that section other than the date of issuance shall be deemed to be 'restricted stock options'; or (2) a savings, investment, or stock purchase plan providing for both (i) periodic payments (or payroll deductions) for acquisition of securities by participating employees and (ii) periodic purchases of the securities by participating employees, or the person acquiring them for the account of such employees.

" $(f)$ This section shall not prohibit any transaction or transactions if the Commission, upon written request or upon its own motion, exempts such transaction or transactions, either unconditionally or on specified terms and conditions, as not constituting a manipulative or deceptive device or contrivance comprehended within the purpose of this section."

${ }^{\top}$ See note 41 infra.

8 SEC v. Georgia-Pacific Corp., '64-'66 CCH Fed. SEC. L. REP. ๆ 91692 (S.D.N.Y. 1966). 
prohibited many activities which are now proscribed by rule $10 \mathrm{~b}-6 .{ }^{\circ}$ Thus, artificially raising the market price of a security in order to obtain a more favorable return from an offering was found to be one of the acts which the statutes were designed to prohibit. ${ }^{10}$ Also held to be illegally manipulative was any attempt, whether in the course of a distribution or otherwise, to affect the "outside" or investors' market by placing increasingly higher bids in the "inside" or dealers' market. ${ }^{11}$ A broker-dealer could violate the regulations even though he had not engaged in the manipulative trading himself, but rather had collaborated with the primary violator. ${ }^{12}$ Moreover, the burden under section 9 (a) of demonstrating that the apparent active trading was undertaken "for the purpose of inducing a purchase" was lessened by the ruling that a prima facie violation would result from a showing that a person with a substantial, direct pecuniary interest in the success of a proposed offering had sought to raise the market

\footnotetext{
- The 1933 and 1934 acts contain broad prohibitions against manipulative activities. Section 17 (a) (3) of the Securities Act makes it unlawful for any person, in the offer or sale of securities, "to engage in any transaction, practice, or course of business which operates or would operate as a fraud or deceit upon the purchaser." $48 \mathrm{Stat}$. 84, as amended, 15 U.S.C. $\$ 77 q(3)$ (1964). Section $9(\mathrm{a})(2)$ of the Exchange Act prohibits transactions which would create a false or misleading appearance of active trading in any security registered on a national exchange for the purpose of inducing a purchase or sale. 48 Stat. 889,15 U.S.C. $\$ 78 i$ (a) (2) (1964). Another paragraph of this section is specifically directed against wash sales or sales in which there is "no change in the beneficial ownership" of the security. 48 Stat. 889,15 U.S.C. $\$ 78 i$ (a) (1) (A) (1964). Section 9 (a) also proscribes matched orders or "orders for the sale [or purchase] of any ... security with the knowledge that an order or orders of substantially the same size, at substantially the same time, and at substantially the same price, for the purchase [or sale, if the first mentioned transaction were a purchase] of such security, has been or will be entered by or for the same or different parties." 48 Stat. 889, 15 U.S.C. 78i (a) (1) (B), (C) (1964). Finally, under $\$ 15$ (c) (1) broker-dealers are prohibited from employing "any manipulative, deceptive, or other fraudulent device or contrivance" to effect transactions in, or induce purchases or sales of, securities traded overthe-counter. 48 Stat. 895, as amended, 15 U.S.C. $\$ 780$ (c) (1) (1964).

${ }^{10}$ E.g., Adams \& Co., 33 S.E.C. 444 (1952) (\$17(a) of the Securities Act and $\$ \$ 10(\mathrm{~b})$ and 9 (a) (2) of the Exchange Act); Thornton \& Co., 28 S.E.C. 208, aff'd, 171 F.2d 702 (2d Cir. 1948) ( $\S 9$ (a) (1) and (2), 10 (b), and 15 (c) (1) of the Exchange Act); Kidder, Peabody \& Co., 18 S.E.C. 559 (1945) (\$\$ 9(a)(2) and 15(c)(1) of the Exchange Act); Russell Maguire \& Co., 10 S.E.C. 332 (1941) (\$17 (a) of the Securities Act and $\S 9$ (a) (2) of the Exchange Act).

${ }^{21}$ E.g., R. L. Emacio \& Co., 35 S.E.C. 191 (1953) ( 17 (a) of the Securities Act and $\S \S 10$ (b) and 15 (c) (1) of the Exchange Act); Floyd A. Allen \& Co., 35 S.E.C. 176 (1953) $(\$ 17$ (a) of the Securities Act and $\$ \S 10(\mathrm{~b})$ and 15 (c) (1) of the Exchange Act); Barrett \& Co., 9 S.E.C. 319 (1941) ( $\$ 15$ (c) (1) of the Exchange Act).

12 See Russell Maguire \& Co., 10 S.E.C. 332 (1941).

Similarly, an underwiter could be penalized by suspension of his registration if a salesman in his firm had requested another trader to create activity in the security being distributed. See Kidder, Peabody \& Co., 18 S.E.C. 559, 571 (1945).
} 
price for outstanding securities of the same issuer..$^{13}$ Also, any activity which would violate section 9 (a) (2) if the security were registered on a national exchange was held to violate sections 17 (a) and 15 (c) if it were not. ${ }^{14}$

Administrative pronouncements presented with more specificity the restrictions to be observed by broker-dealers. In response to an inquiry by a practitioner, the Commission refused to allow the trading department of a firm to buy without restriction securities which were the subject of a distribution by the firm's retailing department. ${ }^{15}$ The Commission ruled that, regardless of departmentalization, a firm was to be viewed as a single business organization. Also to be scrutinized were purchases by a managing underwriter to cover a syndicate short position ${ }^{16}$ while the members of the selling group were still engaged in the retail distribution of the security ${ }^{17}$ or while individual underwriters still held unsold blocks

${ }^{13}$ The Federal Corp., 25 S.E.C. 227, 230 (1947). Similarly, in an administrative release issued four years prior to The Federal Corp., the SEC had announced that any purchase made to facilitate a distribution would be deemed to have been made with the "intention or purpose of inducing the purchase of the offered security by others." Opinion of Director of the Trading and Exchange Division, SEG Exchange Act Release No. 3506 (November 11, 1943).

1t Halsey, Stuart \& Co., 30 S.E.C. 106, 110-12 (1949); Barrett \& Co., 9 S.E.C. 319, 328 (1941). The assertion that $\$ 9$ (a) prohibitions are applicable to transactions in securities not traded on a national exchange apparently involved a statement of general policy and was not intended to imply that the section would be literally applied to an such transactions. In SEC Exchange Act Release No. 1680 (April 29, 1938), the Commission announced its adoption of a rule pursuant to $\S 10$ (b) which extended the prohibitions of $\S 9$ (a) regarding securities registered on the national exchanges to securities traded over-the-counter or on an exempt exchange. In SEC Exchange Act Release No. 1689 (May 3, 1938), the effectiveness of this rule was partially suspended. Finally in 1941 , the rule was repealed altogether "since it does not appear that the rule will be helpful as a clarification and since its present status may lead to confusion." Barrett \& Co., supra at 330 . The motivation for the repeal stemmed from a recognition that certain language in $\$ 9$ (a) was so geared to the workings of an exchange market that its literal application to the over-the-counter market would be misleading. See 3 Loss 1566-67; Andresen, Manipulation of Over-the-Counter Securities Markets, 10 GEO. WASH. L. REv. 639, 643-45 (1942). The applicability of principles developed under $\$ 9$ (a) to proceedings against dealers in the over-the-counter market lhas been questioned. See Comment, 56 YALE L.J. 509, 531-33 (1947).

${ }^{15}$ Opinion of Director of the Trading and Exchange Division, SEC Exchange Act Release No. 3505 (November 16, 1943).

${ }^{10} \mathrm{~A}$ broker-dealer is said to have a short position in a security when the firm has sold a quantity of the security greater than that which it owns. This situation is possible because delivery of securities may be made several days subsequent to their sale. Conversely, if a broker-dealer is obligated to deliver less than its entire trading inventory of a particular security, it has a long position. See Bloomenthal, The Case of the Subtle Motive and the Delicate Art-Control and Domination in Over-theCounter Securities Markets, 1960 Duke L.J. 196, 198 n.3.

${ }^{17}$ Opinion of Director of the Trading and Exchange Division, SEC Exchange Act 
of the security. ${ }^{18}$ Similarly, a syndicate member who had sold his allotment could not resume his normal trading activities until he was certain that any stabilization undertaken by the managing underwriter had ceased. ${ }^{19}$ Eventually, the Commission's rulings were interpreted to require suspension of active trading altogether by any broker-dealer involved in the underwriting or promotion of a distribution. ${ }^{20}$

Promulgation of rule 10b-6. Rule 10b-6, as finally promulgated, is consistent with pre-1955 judicial and administrative decisions in prohibiting activities which are the primary means by which market manipulation might be effected in connection with a public offering. The initial proposal of rule $10 \mathrm{~b}-6,21$ made in 1954, stated the pro-

Release No. 3506 (November 16, 1943). The position taken by the SEC appeared to be that purchases made during the course of a distribution to cover the short position would be assumed to have been made for the purpose of facilitating the distribution unless external factors indicated otherwise. Factors which the Commission evaluated in deciding if purchases were so made include whether the independent market price was above the price established for the offered securities and whether the syndicate manager had attempted to acquire shares away from the market, such as in privately negotiated transactions.

${ }^{18}$ Ibid. While the Commission did not categorically prohibit purchases on the market to cover the syndicate short position when individuals were still long in the security, it did say that "it would also seem appropriate for the agreement between underwriters to contain provisions requiring the individual underwriters, upon request of the manager, to deliver to him unsold securities ... for the purpose of reducing the syndicate short position." Ibid.

10 Opinion of Director of the Trading and Exchange Division, SEC Exchange Act Release No. 3505 (November 16, 1943).

${ }^{20}$ See Foshay, Market Activities of Participants in Securities Distributions, 45 VA. L. REv. 907, 911-12 (1959). The SEC apparently did not view the restrictions on trading activities during a distribution to be applicable to unsolicited brokerage transactions, privately negotiated purchases made off the open market, and purchases by brokerdealers who, even though they were involved in a distribution of the security, were ordinarily the primary market-makers for that security. Ibid.

A case which may have provided much of the impetus for the promulgation of rule 10b-6 was Halsey, Stuart \& Co., 30 S.E.C. 106 (1949), which involved a dealer who had managed the underwriting of a $\$ 45,000,000$ bond issue in the over-the-counter market. Violations of $\S 17$ (a) of the Securities Act and $\S \S 10$ (b) and 15 (c) (1) of the Exchange Act were found when the broker-dealer conducted extensive trading in the bonds while attempting to dispose of a portion of the offering which had not been sold during the registered distribution. The significance of the case lies in its consolidation of principles previously presented by the Commission. See note 14 supra and accompanying text. Further, the decision presented a summary of the philosophy motivating the application of the antimanipulation provisions to purchasing by the distributing dealer during the course of an offering: "Actual buying with the design to create activity, prevent price falls, or raise prices for the purpose of inducing others to buy is to distort the character of the market as a reflection of the combined judgments of buyers and sellers, and to make of it a stage-managed performance." 30 S.E.C. at 112.

${ }^{21}$ SEC Exchange Act Release No. 5040 (May 18, 1954), reprinted at 19 Fed. Reg. 2986 (1954). 
hibitions only in general terms. Bidding and purchasing were proscribed for "any person who has reasonable cause to believe that he will participate, has agreed to participate, or is participating, in a particular distribution of a security." ${ }^{22}$ Since the proposed rule did not prescribe when the prohibition was to commence, the Commission apparently intended that bidding and purchasing should cease as soon as a person could be said to have qualified under the quoted terminology. Also, while some of the exemptions specified under the present form of the rule were available, ${ }^{23}$ no provision was made for granting exceptions in unanticipated situations in which application of the rule was not intended. ${ }^{24}$

Included in the original proposal was a request by the Secretary of the Commission for comments by practitioners. ${ }^{25}$ In response to this invitation came numerous observations and criticisms directed toward the indefiniteness of the proposed rule. Those responding recognized that the term distribution had no well-defined meaning and might apply to transactions upon which limitations had not previously been imposed. ${ }^{26}$ Moreover, the complaint was raised that much uncertainty would result as to when the prohibition was to commence and terminate. ${ }^{2 \pi}$ As a possible resolution of this difficulty it was suggested that the Commission choose a specific point in time prior to a distribution at which trading should cease. ${ }^{28}$ Similarly,

${ }^{22} 19$ Fed. Reg. at 2986 (1954).

${ }^{23}$ Exemptions allowed under the current formulation of $10 \mathrm{~b}-6$ which were present in the original proposal include clauses (i), (iv)-(vi), and (viii)-(x). Paragraphs (c) through ( $f$ ) were added subsequent to the 1954 version. Compare ibid with note 6 supra. See generally notes 223-33 infra and accompanying text.

${ }^{24}$ See 19 Fed. Reg. 2986 (1954).

${ }^{25}$ See $i d$. at 2988.

20 See Letter From Charles C. Glavin, Vice President, First Boston Corporation, to the Securities and Exchange Commission, June 24, 1954; Letter From John F. Ferguson, Merrill Lynch, Pierce, Fenner \& Beane, to the Securities and Exchange Commission, June 18, 1954; Letter From Philip A. Loomis, Jr., O'Melveny \& Myers, to the Securities and Exchange Commission, June $11,1954$.

${ }^{27}$ See Letter From David V. Stern, Jr., Schumacher, Gilmore, Van Ness \& Stern, to the Securities and Exchange Commission, June 18, 1954; Letter From John F. Ferguson, Merrill Lynch, Pierce, Fenner \& Beane, to the Securities and Exchange Commission, June 17, 1954, at 2: "At what point of time must the person to whom the general prohibition apples refrain from a bid, purchase or inducement to purchase and when may he resume such activity? It seems to us that the time to refrain is so indefinite and uncertain .... and the penalty ... so stringent that this provision of the general prohibition should be eliminated."

${ }^{28}$ See Letter From John Mulford, Acting Chairman, American Bar Association, to the Securities and Exchange Commission, June 18, 1954 (seven days prior to distribution); Letter From David V. Stern, Jr., Schumacher, Gilmore, Van Ness \& Stern, to the Securities and Exchange Commission, June 18, 1954 ("some arbitrary point of time"). 
practitioners were almost unanimous in their anticipation of difficulty in distinguishing the classes of persons to whom the prohibition was to extend.29 Besides noting that the Commission had reserved no ad hoc power to grant exceptions, ${ }^{30}$ the critics recognized that the listed exemptions included no allowance for the continuation of normal trading activities ${ }^{31}$-especially those transactions which would not directly affect the market price of an offered security..$^{32}$

The final form of $10 \mathrm{~b}-6,{ }^{33}$ adopted July 5,1955 , preserves the broad scope of the initial proposal but includes additions which are responsive to some of the proffered criticisms. As in the original proposal, the regulatory effect of the rule is directed exclusively to the trader's market activities during a public offering. ${ }^{34}$ Further,

${ }^{20}$ See Letter From Sullivan \& Cromwell to the Securities and Exchange Commission, June 30, 1954; Letter From Charles C. Glavin, Vice President, First Boston Corporation, to the Securities and Exchange Commission, June 24, 1954.

${ }^{30}$ See Letter From Charles C. Glavin, Vice President, First Boston Corporation, to the Securities and Exchange Commission, June 24, 1954 at 2: "There are so many kinds of purchases of a security that it is difficult to foresee all of them. Most would be perfectly proper. Consequently, the rule should have an 'escape valve' to provide latitude to the Commission to permit exceptions to the rule when such exceptions are deemed appropriate."

32 One of the most pointed responses criticized the Commission's proposal as in consistent with the practices permitted under the accepted interpretations of the other antimanipulation provisions. Activties which a group of practitioners felt should be allowed to continue despite a trader's participation in a distribution included (1) purchases for the trader's investment account which were made in accordance with his normal investment activity, (2) exercise of rights or conversion privileges in respect to securities beneficially held, (3) purchases to cover short positions or sales to liquidate long positions which had resulted from normal trading prior to the distribution, and (4) solicitation with a view to acquisition of large blocks of shares privately held. These proposals were included in a letter to Ralph $\mathrm{H}$. Demmler, Chairman, Securities and Exchange Commission, and signed by Edward H. Ladd III, Chairman, First Boston Corporation; Eugene E. Barry, Shields \& Co.; Philip W. Brown, Smith, Barney \& Co.; Frank J. Coyle, New York Stock Exchange; Paul Devlin, Blyth \& Co.; Herbert S. Hall, Morgan Stanley \& Co.; William D. Kerr, Baccon, Whipple \& Co.; and Charles L. Morse, Jr., Hemphill, Noyes \& Co.

It is significant to note that while none of the practices listed above was permissible under a literal reading of the initially proposed version of $10 \mathrm{~b}-6$, the form of the rule finally adopted specifically exempted (2) and (4). See note 6 supra.

${ }^{32}$ See Memorandum From Wm. Ward Foshay, Sullivan \& Cromwell, to the Securities and Exchange Commission, February 21, 1955.

For example, while $10 \mathrm{~b}-6$ (a) allows certain types of purchases made pursuant to unsolicited offers, a feeling still exists among practitioners that purchases which are privately negotiated, whether or not originally solicited by the trader, should be exempted. See Memorandum to Clients from Sullivan \& Cromwell, May 12, 1966.

${ }^{38} \mathrm{~A}$ revised proposal of the rule was presented in SEC Exchange Release No. 5159 (April I9, 1955), reprinted at 20 Fed. Reg. 2826 (1955). This revised form was officially adopted without substantive alteration in SEC Exchange Act Release No. 5194 (July 5, 1955), reprinted in final form at 17 C.F.R. $\$ 240.10$ b-6 (1964, Supp. 1966).

${ }^{34}$ By contrast, $\S 17$ of the Securities Act and $\S \S 9$ (a) and 15 (c) of the Exchange Act 
only bidding and purchasing are proscribed..$^{35}$ The prohibition of these activities is absolute ${ }^{36}$ and extends to both exchange $\mathrm{e}^{37}$ and over-

are applied without regard to the phase of the trader's operation which is called into question. Compare Halsey, Stuart \& Co., 30 S.E.C. 106 (1949) with M. S. Wien \& Co., 23 S.E.C. 735 (1946).

Certain other trading rules adopted by the Commission pursuant to statutory provisions are directed solely to the area of distributions, but none of these presents a complete prohibition on trading. Rule 10b-2 prohibits any individual "participating or otherwise financially interested in" a distribution from compensating any person for soliciting the purchase of a distributed security or for purchasing any such security for any account other than that of the person paying the compensation. An exemption is allowed for any compensation paid in accordance with a plan which has been filed with the SEC by a national exchange. Also, the prohibition does not encompass salaries paid to regular employees. 17 C.F.R. $\$ 240.10 \mathrm{~b}-2$ (1964); see also Whitney, Rule 10b-6: The Special Study's Rediscovered Rule, 2 MicH. L. REv. 567, 585 n.74 (1964). Rule 15cl-6 requires a broker-dealer to disclose his interest in an over-the-counter distribution. 17 C.F.R. $\$ 240.15 \mathrm{cl}-6$ (1964). Rule 15cl-8 requires offers made "at the market" during a nonexchange distribution to have reference to a competitive market. 17 C.F.R. $\$ 240.15 c I-8$ (1964).

The unique problems presented during a distribution were summarized by the Commission in Bruns, Nordeman \&: Co., 40 S.E.C. 652,660 n.11 (1961): "A person contemplating or making a distribution has an obvious incentive to artificially infiuence the market price of the securities in order to facilitate the distribution or to increase its profitability."

${ }^{35}$ On the other hand, $\$ 17$ of the Securities Act makes unlawful "any transaction ... which ... would operate as a fraud or deceit upon the purchaser." (Emphasis added.) Sections 9 (a) and 15 (c) of the Exchange Act apply with a similar breadth. See note 9 supra.

30 The 10b-6 concept of distribution partially subsumes the intent requirement of \$9. See note 13 supra and accompanying text. Yet, $10 \mathrm{~b}-6$ clearly goes beyond prohibiting only manipulative purchases. For example, purchases for an employee stock plan, which are prohibited during a distribution without a showing of fraudulent purpose, see Foshay, supra note 20 , at $933-37$, cannot presumptively be viewed as inducement for others to enter the market as might excessively active trading.

In many decisions a "willful" violation of $10 \mathrm{~b}-6$ is found. See, e.g., C. A. Benson \& Co., SEC Exchange Act Release No. 7044 (March 26, 1963); Bruns, Nordeman \& Co., 40 S.E.C. 652 (1961). Such a finding is not required by the rule, but is necessary under $\S 15(\mathrm{~b})(5)$ of the Securities Exchange Act in order to justify revocation of a broker-dealer's registration. See 78 Stat. 571 , 15 U.S.C. 780 (b) (5) (1964). Consequently, a proceeding against an "issuer or other person on whose behalf the distribution is made" need not consider the willfulness of the violation: a showing need only be made that there is an intent to do the act which violates the law. See Tager v. SEC, 344 F.2d 5, 8 (2d Cir. 1965); Bruns, Nordeman \& Co., supra at 659. While no decision has specified the precise nature of the prohibited activity, the majority of cases involve purchasing with the intent to raise the market price of a security. However, in view of the absolute nature of the prohibition on purchasing, acquisitions prompted by a non-price-raising motive would be equally unlawful. $C f$. SEC v. Scott Taylor \& Co., 183 F. Supp. 904, 908 (S.D.N.Y. 1959). Though the Commission has asserted that it would revoke the registration of a broker-dealer who sought only to support the then current market price, see ibid., no case has been reported in which this type of violation was for a purpose other than directly to facilitate the distribution. Nonetheless, it is established that in injunction proceedings all that need be shown is a violation of some regulation under the 1933 or the 1934 act. See SEC v. R. A. Holman \& Co., '64-'66 CCH FED. SEc. L. REP. I 91554 (S.D.N.Y. 1965), aff'd, 366 F.2d 456 (2d Cir. 1966). 
the-counter ${ }^{38}$ market transactions. In answer to practitioner criticism, $10 \mathrm{~b}-6$ (a) enumerated three categories of persons to whom the prohibition extended: underwriters, other participating brokerdealers, and issuers or other persons for whom the distribution is made. $^{39}$ Furthermore, besides an attempted specification of the period of prohibition, ${ }^{40}$ the newer formulation includes a reservation by the Commission of an ad hoc power to grant exemptions. ${ }^{41}$

The Commission has consistently ruled that sanctions will be imposed despite a showing that the public sustained no loss by the attempts to affect the distribution. Thus, proof that the efforts of the individual against whom proceedings have been initiated were unsuccessful is of no consequence. Russell Maguire \& Co., 10 S.E.C. $332,350-51$ (1941). Nor is the individual benefited by the fact that the market price would have risen even without his intervention. See Sidncy Tager, SLC Exchange Act Release No. 7368 (July 14, 1964), affd, 344 F.2d 5 (2d Cir. 1965); Gob Shops of America, Inc., 39 S.E.C. 92, 101 (1959). Similarly, it is no defense that a bona fide belief existed that the securities were underpriced at their premanipulation level. Gob Shops of America, Inc., supra at 101-02; Halsey, Stuart \& Co., 30 S.E.C. 106, 112 (1949). Sce also Affidavit in Support of Motion for Preliminary Injunction, p. 3, SEC v. Georgia-Pacific Corp., '64-'66 CCH FED. SEC. L. REP. ๆ 91692 (S.D.N.Y. 1966). Finally, just as the individual is not assisted by a showing that independent broker-dealers supported the price of the security after it had been manipulated, see, e.g., Shearson, Hammill \&: Co., SEC Exchange Act Release No. 7743 (November 12, 1965); J. H. Goddard \&: Co., SEC Exchange Act Release No. 7618 (June 4, 1965); Theodore A. Landau d/b/a Landau Co., 40 S.E.C. 1119, 1126 (I962), he will not be benefited by a claim that skilled investors actually purchased the stock at the artificial price level. See Russell Maguire \& Co., supra at 349-50.

${ }^{3 \tau}$ Seetion 9 of the Exchange Act, on the other hand, applies only to activitics on a national exchange. Sce note 9 supra.

${ }^{38}$ By contrast, the applicability of $\S 15$ (c) is limited to the over-the-counter market. See $i$ ibid.

${ }^{39}$ See note 6 supra for the text of the rule. The limitations imposed by $\S 15$ (c) of the Exchange Act apply only to broker-dealers and do not extend to an "issuer or other person on whose behalf such a distribution is made." See note 9 supra.

${ }^{10}$ Sce $10 \mathrm{~b}-6$ (a) (xi) and (c) (3), note 6 supra. Sce generally notes 176-204 infra and accompanying text.

${ }^{12}$ See $10 \mathrm{~b}-6(\mathrm{f})$, note 6 supra.

Despite the distinctive nature of $10 \mathrm{~b} \cdot 6$, decisions under the other antimanipulation provisions have precedential value when $10 \mathrm{~b}-6$ is invoked. For example, the 1949 decision in Halsey, Stuart \& Co., 30 S.E.C. 106, has been cited in SEC v. Scott Taylor \&: Co., 183 F. Supp. 904 (S.D.N.X. 1959); J. H. Goddard \& Co., SEG Exchange Act Release No. 7618 (June 4, 1965); Thcodore A. Landau d/b/a Landau Co., 40 S.E.C. 1119 (1962); Bruns, Nordeman \& Co., 40 S.E.C. 652 (1961); and Gob Shops of America, Inc., 39 S.E.C. 92 (1959), as an exemplification of the Commission's philosophy that purchasing by a trader involved in a distribution distorts the competitive nature of a securities market. This use of precedent is consistent with the Commission's view, expressed upon promulgation of the rule, that $10 \mathrm{~b}-6$ is a "formulation of principles which historically have been applied in considering questions relating to manipulative activity." SEC Exchange Act Release No. 5040 (May 18, I954), reprinted at 19 Fed. Reg. 2986 (1954). See also SEC Exchange Act Release No. 5194 (July 5, 1955), reprinted at 20 Fed. Reg. 5075 (1955). Further, many activities which would amount to violations of $10 \mathrm{~b}-6$ could be, and often are, prosecuted as violations of other antimanipulation sections. For example, any apparent or actual activity created by pur- 
Despite the inclusion of those new elements, later case developments have revealed the presence of many difficulties in the practical interpretation of the rule. Especially troublesome is the lack of a definitive analysis of the term distribution. Also, extensive administrative and judicial constructions have been needed to clarify further when the prohibition against bidding and purchasing commences and terminates. The remainder of this comment focuses upon the resolutions offered and further problems presented by the decisional analysis given to the concept of distribution and to the duration of the period of prohibition. Also to be considered are the types of activities prohibited, the classes of persons to whom the prohibition extends, and the exemptions enumerated in the text of rule $10 \mathrm{~b}-6$.

\section{The Concept of a Distribution}

The term distribution as used in the Securities Act has been defined for some purposes. Rule $154,{ }^{42}$ promulgated under section $4(4)^{43}$ of that act, was intended to facilitate the determination of whether the magnitude of a particular securities transaction is such that registrants should be required to make full and adequate disclosure of all relevant information. ${ }^{44}$ The criterion under rule 154 for evaluating the size of the offering is whether the block of securi-

chasing during a distribution will also violate 17 G.F.R. $\$ 240.10 \mathrm{~b}-5$ (1964) if the manipulator fails to disclose that the market is not completely competitive because of his intervention. See, e.g., J. H. Goddard, supra; C. A. Benson \& Co., SEC Exchange Act Release No. 7044 (March 26, 1963); MacRobbins \& Co., SEC Exchange Act Release No. 6846 (July 11, 1962); Sterling Securities Co., 39 S.E.C. 487, 492 (1959). 17 C.F.R. $\$ 240.15 \mathrm{cl}-8$ (1964) prohibits a broker-dealer in the over-the-counter market from representing to customers that he is offering a security "at the market" when lie does not lave "reasonable grounds to believe that a market for such security exists other tban that made, created, or controlled by him ...." See, e.g., SEC v. Electronics Security Corp., 217 F. Supp. 831, 836-37 (D. Minn. 1963); Woods \& Co., SEC Exchange Act Release No. 7178 (November 29, 1963). See generally 3 Loss 1480-81. Also, if a broker-dealer attempts a Regulation A offering, see 17 C.F.R. $\$ \$ 230.601-.610$ (a) (1964), which exempts from registration certain offerings the aggregate price of which does not exceed 300,000 dollars, he may be found to have violated the provisions of that regulation if his manipulation lias raised the price at which part of the distribution is sold in such a manner that the aggregate price of the offering actually exceeds the statutory limitation. See C. A. Benson \& Co., supra; Lewisoln Copper Corp., 38 S.E.C. 226 (1958).

$\$ 17$ C.F.R. $\$ 230.154$ (1964, Supp. 1966).

¿ 48 Stat. 77, as amended, 15 U.S.C. $\$ 77 d(4)$ (1964).

"See generally 1 Loss 697-708; Delaney, The Whys and Wherefores of Investment Letters, 30 Fordham L. REv. 267-70, 278-79 (1961); Gilchrist \& Hanna, Secondary Distribution of Corporate Securities, 13 Sw. L.J. 1, 2-8, 15-20, 27-32 (1959); Note, Distribution of Exempt Securities Under Section $f(1)$ of the Securities Act of 1933, I6 U. Miami L. REv. 319, 326-30 (196I). 
ties is substantial in terms of the total number of shares outstanding and the aggregate volume of trading in such security. Apart from this definition and one other minor provision, ${ }^{45}$ neither the statutory sections nor the rules include a definition of distribution.

Within a short period after the promulgation of $10 \mathrm{~b}-6$, the Commission concluded that while distributions registered under the Securities Act are certainly within the ambit of the rule, exemption from registration does not necessarily ensure exemption from the purview of 10b-6.46 Consequently, the limitations imposed by the rule were extended to trading in large blocks of securities involved in less formalized transactions. Precedent has firmly established that unregistered distributions of large blocks of securities acquired from an issuer or a person controlling the issuer are subject to the restrictions of $10 \mathrm{~b}-6.47$ Moreover, the decisions indicate that transactions involving large blocks of securities need not be accompanied by a formalized underwriting structure in order to fall within $10 \mathrm{~b}-6.48$ Distributions have been found when even an informal syndicate is lacking, ${ }^{49}$ and some rulings have applied the $10 \mathrm{~b}-6$ prohibition when only one broker-dealer was involved in the distribution.50 On the other hand, it is not uncommon in those cases where more than one

\footnotetext{
${ }^{15}$ Another definition of distribution is found in 17 C.F.R. $\$ 230.140$, promulgated pursuant to the statutory section defining "underwriter." 48 Stat. 75 (1933), 15 U.S.C. $\$ 77 b(11)$ (1964). The rule, the purpose of which is to clarify the status of a very particularized factual situation, states that when a person's business consists mainly of buying the securities of any one issuer and disposing of his own securities to supply proceeds with which to acquire those other securities, that person "is to be regarded as engaged in the distribution of the securities of such issuer. ..." This rule does not share any meaningful relationship with the definition of distribution developed under rule $10 \mathrm{~b}-6$.

${ }^{16}$ See SEC v. Scott Taylor \& Co., 183 F. Supp. 904 (S.D.N.Y. 1959); Bruns, Nordeman \& Co., 40 S.E.C. 652, 660 (1961); Gob Shops of America, Inc., 39 S.E.C. 92, 103 n.25 (1959); Foshay, supra note 20, at 920.

${ }^{17}$ See, e.g., F. S. Johns \& Co., SEC Exchange Act Release No. 7972 (October 10, 1966), aff'd sub nom. Dlugash d/b/a Douglas Enterprises v. SEC, 373 F.2d 107 (2d Cir. 1967); J. H. Goddard \& Co., SEC Exchange Act Release No. 7618 (June 4, 1965); A. T. Brod \& Co., SEC Exchange Act Release No. 7139 (September 11, 1963); Sutro Bros. \& Co., SEC Exchange Act Release No. 7053 (April 10, 1963); cf. Woods \& Co., SEC Exchange Act Release No. 7178 (November 29, 1963).

In F. S. Johns \& Co., supra, a purchase made by the registrant from an account of an incorporated brokerage house, the president of which was a controlling person of the issuer of the securities purchased, was held to be a purchase from a controlling person of the issuer.

${ }^{18}$ See SEC v. Scott Taylor \& Co., 183 F. Supp. 904 (S.D.N.Y. 1959); Bruns, Nordeman \& Co., 40 S.E.C. 652 (1961).

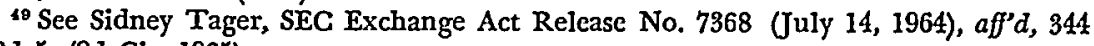
F.2d 5 (2d Cir. 1965).

${ }_{\text {so }}$ Batten \& Co. v. SEC, 345 F.2d 82 (D.C. Cir. 1964).
} 
broker-dealer is involved for a co-participant to be deemed an underwriter only after an administrative evaluation of all the relevant facts. ${ }^{\text {} 1}$

The Report of Special Study of Securities Markets of the Securities and Exchange Commission ${ }^{52}$ revealed that many large firms did not strictly observe $10 \mathrm{~b}-6$ when involved in sales of large blocks of securities not acquired subject to a formal agreement with the issuer. ${ }^{53}$ This disregard for the regulatory provisions was especially prevalent when a broker-dealer was disposing of his inventory position in a security through the use of a public market. ${ }^{54}$ Furthermore, there is little evidence that pre- $10 \mathrm{~b}-6$ practice curtailed trading in similar cases where the transaction was informally executed and did not involve an unusually large quantity of securities. ${ }^{55}$

${ }^{51}$ See Sutro Bros. \& Co., SEC Exchange Act Release No. 7053 (April 10, 1963).
${ }^{52}$ H.R. Doc. No. 95, 88th Cong., Ist Sess. (1963) [hereinafter cited as Special Study]. The Report of the Special Study is the culmination of the efforts of approximately sixty-five persons, including lawyers in private practice, personnel from the SEC's own staff, economists, and professors. Authorized under $\$ 19$ (d) of the Exchange Act, the purpose of the Study was to investigate "the adequacy, for the protection of investors, of the rules of national securities exchanges and national securities associations. . .." 48 Stat. 899, as amended, 75 Stat. 465 (1961), 15 U.S.C. $\$ 78 \mathrm{~s}$ (d) (1964). While the Study group worked closely with the Commission, the final recommendations were intended to represent an independent viewpoint without official approval. See Special Study, pt. 1, Letter of Transmittal by William L. Cary, Chairman, Securities and Exchange Commission, iv-v; Cary, The Special Study of Securities Markets of the Securities and Exchange Commission, 62 Mrct. L. REv. 557, 560-61 (1964). The final report, con. taining more than 3,000 pages in six parts, covers a wide range of topics in connection with market transactions, from the qualifications of persons in the securities industry to the selling practices of open-end investment companies. For a summary of the Commission's response to the report submitted by the Study, see SEC Special Market Study Release No. 25 (April 30, 1963). Summaries of actions actually taken on the recommendations made in the Special Study are recorded in Cary, supra, at 562-66; Cohen, Recommendations of the Special Study of Security Markets, 53 ILL. B.J. 284 (1964).

${ }^{58}$ See Special Study, pt. 1, 542-47, 566, 570. The conclusion to be drawn from the Report of the Special Study and the authorities cited in notes 46.47 supra is that the source of securities sold is of minimal importance in determining the applicability of the rule. The source may, however, have significance in the actual proceeding against a broker-dealer. For example, if the securities are purchased from an issuer, the Commission may arm itself with the additional prohibition against selling unregistered securities contained in $\$ 5$ of the Securities Act. A finding of a violation under this section would require that the broker-dealer fall within the definition of underwriter contained in $\$ 2$ (11) of the Securities Act. The definition in that section provides that "any person who has purchased from an issuer with a view to, or offers or sells for an issuer in connection with, the distribution of any security ..." shall be deemed an underwriter. See Sutro Bros. \& Co., SEC Exchange Act Release No. 7053, at 7-8 (April 10, 1963). See also C. A. Benson \& Co., SEC Exchange Act Release No. 7044 (March 26, 1963).

s4 Special Study, pt. 1, 547.

${ }^{65}$ See Letter From Philip A. Loomis, Jr., O'Melveny \& Myers, to the Securities and Exchange Commission, June 11, 1954. 
Because neither prior practice nor post- 1955 rulings have clarified the circumstances under which the rule's prohibition applies, it is here that the need for a more exacting analysis of the components of the 10b-6 distribution concept is most pressing. The Special Study recognized the confusion and called for a "clarification by the Commission of the intended impact of the rule . . ."."s The SEC responded: "We agree ... that the Commission should take appropriate steps to clarify the application of Rule $10(b)(6)$ and shall take the necessary action." ${ }^{57}$ Nevertheless, apart from routine issues decided in later Commission proceedings, no definitive analysis has been made of the applicability of the term to the various possible situations in which a broker-dealer or issuer might dispose of a significant position in a particular security.

"Major selling effort." The most probing administrative and judicial interpretations of the meaning of distribution, which are still pre-Special Study decisions, have presented only broad outlines for the term's application. Gob Shops of America, Inc. ${ }^{58}$ involved a Regnlation A offering ${ }^{58}$ in which the distributing broker-dealer placed progressively higher bids in the National Daily Quotation Sheets despite the fact that he retained a long position in the security. In determining that a distribution as contemplated by rule $10 \mathrm{~b}-6$ need not be an offering registered under the Securities Act, the SEC concluded that "it is enough if the broker or dealer is engaged in a distribution in the sense of a major selling effort in his own behalf." Unfortunately, this 1959 ruling did not include a definitive breakdown of the elements of the "major selling effort" concept.

Probably because the rule $154^{01}$ definition of distribution focuses on the number of shares of one issuer sold relative to the total number outstanding, the criterion proffered in Gob Shops was thought to imply that the number of shares sold by a particular broker-dealer must be appreciable in terms of the total number outstanding. ${ }^{22}$ However, in 1960, the Commission made clear its position that "major selling effort" was to be evaluated in terms of the particular

\footnotetext{
${ }^{86}$ Special Study, pt. 1, 547.

57 SEC Special Study Release No. 25 (April 30, 1963).

5839 S.E.C. 92 (1959).

${ }^{50}$ See note 41 supra.

${ }^{60} 39$ S.E.C. at 103 n.25. (Emphasis added.)

${ }^{61}$ See note 42 supra and accompanying text.

${ }^{62}$ See Whitney, supra note 34 , at 582-83.
} 
broker-dealer's activity in the security. In Scott Taylor \& Co., counsel for one of the broker-dealers involved argued that no "major selling effort" could be found since his client handled less than onehalf of one per cent of the outstanding shares of the distributed security. ${ }^{63}$ The Hearing Examiner, whose findings were approved by the Commission, ${ }^{64}$ rejected this contention and found that the number of shares sold, which represented "an aggregate cash expenditure by the public in excess of $\$ 150,000$ in a period of less than four months' time," was substantial in light of the broker-dealer's normal volume. ${ }^{65}$

Functional approach. In Bruns, Nordeman \& Co., ${ }^{66}$ a case factually identical to Gob Shops, the Commission, premising its interpretation upon the notion that distribution is to be defined in terms of the purpose of $10 \mathrm{~b}-6$, reasoned that the rule should apply whenever an offering is of such significance that the distributor's open market purchasing must be prevented in order to ensure that the market price is ascertained by independent, competitive purchasing. ${ }^{\text {"7 }}$ Taken alone, this definition seems only to confirm the term's lack of definitude. However, the Commission, in attempting to distinguish a distribution from normal trading activity, established two criteria by which to evaluate a particular offering: the magnitude of the block to be marketed ${ }^{68}$ and the selling efforts and methods employed. Yet it is not clear from the Commission's analysis what type of selling efforts and methods not normally undertaken can be pursued by a broker-dealer without his having to conform to $10 \mathrm{~b}-6$ restrictions. ${ }^{69}$

${ }^{63}$ See Recommended Decision of Hearing Examiner, p. 25, August 15, 1960, in Scott Taylor \& Co. (reported with Theodore A. Landau d/b/a Landau Co.), 40 S.E.C. 1119 (1960).

64 See 40 S.E.C. at 1125.

Ex See Recommended Decision of Hearing Examiner, p. 26, August 15, 1960, in Scott Taylor \& Co. (reported with Theodore A. Landau d/b/a Landau Co.), 40 S.E.C. 1119 (1960).

es 40 S.E.C. 652 (1961).

${ }^{67} \mathrm{Id}$. at 660 .

68 Ibid.

By implication the term magnitude refers to a block larger than that involved in normal trading activity. On this basis, it might be argued that the Commission intended to make the existence of a distribution depend upon a particular broker-dealer's average trading volume in a security. Later cases, however, do not develop this approach. For example, no indication has been given as to the period over which an average should be ascertained. Consequently, a broker-dealer can anticipate difficulty predicting whether a particular block would have sufficient magnitude to qualify as a distribution.

${ }^{80}$ In Bruns, Nordeman the Commission did give a limited indication of the type of 
The merit of this functional approach lies in the flexibility with which the Commission can enforce the rule. The prohibition may be extended to activities which impair the maintenance of a competitive market but which may not have been specifically proscribed by the letter of the regulation. The generally stated interpretation equips the Commission for comprehensive policing of the particularly troublesome area of distributions. Within the gamut of possible securities transactions, it is here that the profit motive will most likely tempt an artificial intervention into the public market.70 Furthermore, the lack of definitional precision facilitates consideration of potentially manipulative practices with reference to the circumstances of the particular trader involved: the broker-dealer with a large normal trading volume can be brought within the rule's limitations as well as one who has had little market experience with the security apart from the large block to which application of $10 \mathrm{~b}-6$ is questioned. Finally, any interpretation which proposed exactitude in the scope of the concept of distribution might encourage schemes designed to avoid the prohibition of the rule.

Nevertheless, the functional analysis presented in Bruns, Nordeman, while ensuring flexibility in enforcement, offers little to assist the broker-dealer in determining the applicability of the rule when the block to be traded is abnormal in terms of his usual position in the security but not sufficiently significant to require that a registration statement be filed. ${ }^{71}$ The logical alternative to a general definition is, of course, one which attempts to designate specifically the cri-

selling effort it felt was relevant to a consideration of the applicability of $10 \mathrm{~b} \cdot 6$ when, on the particular facts of that case, a finding was made that the registrant had engaged in a continuous selling effort. 40 S.E.C. at 660 . Other factors which have been considered in evaluating the type of selling effort include whether extra commissions have been paid to salesmen effecting transactions in a particular security, see Special Study, pt. 2, 584; 3 Loss 1597; whether the broker-dealer has recommended the security to his customers in a market letter, see J. H. Goddard \& Co., SEC Exchange Act Release No. 7618 (June 4, 1965); and whether purchases have been solicited from persons not previously customers of the broker-dealer, F. S. Johns \& Co., SEC Exchange Act Relcase No. 7972 (October 10, 1966), aff'd sub nom. Dlugash d/b/a Douglas Enterprises, 373 F.2d 107 (2d Cir. 1967).

$7^{70}$ See Bruns, Nordeman \& Co., 40 S.E.C. 652,660 n.11 (1961).

The underwriting broker-dealer is, of course, interested in maximizing the profitability of his efforts. Further, even if the underwriting syndicate has purchased the entire issue and has, therefore, insured that the issuer will receive the fnnds sought in this offering, the issuer has an interest in the market reception of his issue; for the success of its dispersion will affect the willingness of underwriters to assume the risk of a future distribution.

${ }^{71}$ See Special Study, pt. 1, 545-47, 566-70; Whitney, supra note 34, at 586-87. 
teria for a 10b-6 distribution. Since the initial proposal of the rule, recommendations have been made which incorporate more precise limits for the distribution concept. One of the letters submitted in 1954 called for a definition in terms of the specific dollar amount to be realized from the offering of the security. ${ }^{72}$ It was further submitted that deference should be given the rule 154 definition of distribution $^{73}$ and its attempts to reach a clear standard by comparing the size of the block involved with the number of outstanding shares of the same class and issuer. ${ }^{74}$ The Special Study reported the recommendation of a large member firm of the New York Stock Exchange that "the definition should be precise as to the size of the offering, number of shares, etc., and not phrased in general terms." 75 Presumably, as a consequence of rejecting the functional definition in favor of a more precise formulation, broker-dealers could identify with more certainty those acts which violate rule $10 \mathrm{~b}-6$. Those manipulative activities which now fall within the rule's prohibition but which would not be encompassed by a more precise redefinition could be prosecuted under other antimanipulation provisions. ${ }^{76}$

\footnotetext{
${ }^{72}$ Letter From Philip A. Loomis, Jr., O'Melveny \& Myers, to the Securities and Exchange Commission, June II, 1954.

${ }^{73}$ See notes 42.45 supra and accompanying text.

${ }^{74}$ The standards under rule 154 for ascertaining whether a registration statement need be filed compare the number of securities proposed to be sold to the total number of the same class outstanding for the same issuer. See 17 C.F.R. $\$ 230.154$ (b). On the other hand, the presence of a "major selling effort" or distribution for $10 \mathrm{~b}-6$ purposes is determined on the basis of the broker-dealer's normal position in the particular security. See notes 61-65 supra and accompanying text. Therefore, any adaptation of the rule 154 standards for determining the applicability of rule $10 \mathrm{~b}-6$ would necessitate a fundamental alteration in Commission policy. As a consequence of such a policy change, many transactions currently treated as within the purview of the rule would be excluded since the percentage of shares involved would not exceed the minimum presented in rule 154. See, e.g., SEC v. Scott Taylor \& Co., 183 F. Supp. 904 (S.D.N.Y. 1959). Further, since rule 154 was promulgated to insure adequate disclosure of information necessary for a discriminate investment decision and since the adoption of rule 10b-6 does not reveal a similar purpose, the choice of the standards presented by the former does not appear to be logically compelled. Arguably, the occurrence of cases where a relatively small percentage of the total outstanding shares of a particular class are involved (see, e.g., ibid.) would suggest that rule 154 standards may be inadequate for effective 10b-6 enforcement. But see note 76 infra and accompanying text. Also relevant to an evaluation of the acceptability of rule 154 criteria is the conclusion of a former member of the Securities and Exchange Commission that "it would be surprising if the industry would, as the price of certainty of application of Rule 10b-6, agree that the latter xule should take on the 'strait jacket' characteristics of Rule 154." Whitney, Rule 10b-6: The Special Study's Rediscovered Rule, 62 MIcH. L. Rev. 567, 581 (1964).

${ }^{75}$ Special Study, pt. 1, 568.

${ }^{70}$ See note 41 supra. It is arguable that use of antimanipulation provisions as a
} 
The Commission's view. While the SEC has conceded the need for clarification of the term distribution, ${ }^{77}$ it is questionable whether any redefinition the Commission might undertake would significantly alter the generality of the present standards. This observation is suggested by the Commission's position in one of the $J$. $H$. Goddard of Co. opinions. ${ }^{78}$ On a motion to dismiss the proceedings against it, the registrant argned that because of the lack of definitive guidelines as to what constituted a distribution, rule 10b-6 was unconstitutional for vagueness. The Commission refused to question the legitimacy of the rule because it had been presented no facts against which to test the allegation. However, the majority added that previous cases, including Bruns, Nordeman, had presented sufficient standards by which an experienced securities dealer such as the registrant could conduct his activities. ${ }^{79}$ Arguably then, much of the vagueness presented to a layman upon an examination of case precedent would be eliminated in practice by the professionalism of broker-dealers. ${ }^{80}$

supplement to $10 \mathrm{~b}-6$ was within the contemplation of the Commission when it stated, upon the initial adoption of the rule, that $10 \mathrm{~b}-6$ was not intended to apply to all possible manipulative activities which might arise. SEC Exchange Act Release No. 5194 (July 5, 1955), reprinted at 20 Fed. Reg. 5075 (1955); see SEC Exchange Act Release No. 5040 (May 18, 1954), reprinted at 19 Fed. Reg. 2986 (1954).

${ }^{77}$ See text accompanying note 57 supra.

${ }^{78}$ SEC Exchange Act Release No. 7321 (May 22, 1964).

${ }^{79} \mathrm{Id}$. at 5 . The Commission further asserted that since proceedings against broker-dealers are remedial, and not penal, in nature, the standards of certainty required in criminal proceedings do not apply. Ibid. While this contention has validity if only legal requirements are considered, it offers little justification for any confusion which may result from the vagueness of the term distribution. The preferable criteria would seem to be not what the Commission must show in order to revoke a brokerdealer's registration, but rather what a practitioner-broker-dealer, issuer, or counselmust know in order to effectuate the stated policy of the rule to protect the investing public.

${ }^{80}$ The prohibition of the rule, however, extends not only to broker-dealers, but also to "the issuer or other person on whose behalf such a distribution is being made." Rule 10b-6 (a) (2). The expertise of these latter classes, especially small issuers, is likely to be significantly less than that of the professional broker-dealer; and consequently, the guidelines presented in prior cases would be less meaningful than they were assumed to be in $J . H$. Goddard \& $\mathrm{Co}$.

Loss states that 'in the absence of a definition of 'distribution,' the indicia include the absolute and relative size of the offering, the number of proposed offerees, the required distributive effort, the presence of a selling group, the payment of a special commission to salesmen, and the degree of a particular broker-dealer's concentration on pushing the one security." 3 Loss 1597. While the suggested criteria might provide a basis for analyzing distribution in some situations, Commission interpretations indicate that the scope of the concept is broader than Loss' evaluation. For example, in SEC v. Scott Taylor \& Co., 183 F. Supp. 904 (S.D.N.Y. 1959), a distribution was found when less than $5 \%$ of the total outstanding shares of an issuer were marketed without a selling 
Other types of distributions. Distributions have been found in situations which have not required an examination of the magnitude of sales or quality of marketing efforts employed. First, in $S E C v$. Georgia-Pacific Corp. ${ }^{81}$ the exchange of one corporation's stock for the securities of another during the course of an acquisition or merger was held to bear sufficient relation to the type of situation meant to be governed by $10 \mathrm{~b}-6$ policies to justify application of that rule. Since the number of shares to be exchanged was partially dependent upon the market price of the stock during certain valuation periods, the SEC successfully prevented interested persons from interfering with the competitive nature of the market. The distribution necessary to invoke $10 \mathrm{~b}-6$ apparently occurred when GeorgiaPacific shares were dispensed to holders of securities of the acquired corporation in exchange for their stock. ${ }^{82}$

Another situation distinguishable from the broker-dealer cases was presented in Pappas $v$. Moss. ${ }^{83}$ Here, the sale of shares to private investors by corporate directors was deemed a distribution, so that purchases by insiders were in violation of $10 \mathrm{~b}-6$ and served as a basis for liability to those holding shares prior to the purchases. This application of $10 \mathrm{~b}-6$ to a non-public distribution of securities was without precedent. ${ }^{84}$ Moreover, the application appears to be a mis-

group or special selling commissions. As guidelines for practical application, "the required distributive effort" and "the degree of a particular broker-dealer's concentration on pushing the one security" possess the same infirmities inherent in the Bruns, Nordeman analysis. However, the Loss approach does serve to re-emphasize that the Commission's analysis does not delineate the term distribution in readily identifiable components.

81 '64-'66 CCH FED. SEC. L. REP. ๆ 91692 (S.D.N.Y. 1966).

${ }^{82}$ See generally notes $123-38$ infra and accompanying text.

${ }^{83} 257$ F. Supp. 345 (D.N.J. 1966).

8s In light of the fact that violations of $10 \mathrm{~b}-6$ generally encompass violations of $10 \mathrm{~b}-5$, see note 41 supra and accompanying text, the desirability of using $10 \mathrm{~b}-6$ as a basis for civil liability is questionable. While the scope of the applicability of $10 \mathrm{~b}-5$ in private litigation has been established by extensive precedent, any interpretation of rule $10 \mathrm{~b}-6$ in a private suit would be made without benefit of prior judicial analysis. Further, a violation of rule $10 \mathrm{~b}-5$ can be found without reliance upon technical terms such as distribution. Thus, employment of rule $10 \mathrm{~b}-6$ instead of $10 \mathrm{~b}-5$ offers few, if any, advantages.

The difficulty which a court might have in applying $10 \mathrm{~b}-6$ to a private action is exemplified by Schraufnagel v. Broadwall Sec., Inc., FED. SEC. L. REP. f 91827 (S.D.N,Y. 1966). When asked to find that a distribution was being effected by a securities dealer who had been the sole market for a security and who had sold substantial blocks of the security, the court refused to reach that conclusion. However, while the court failed to find a distribution "as that term is used in the rule," it did recognize that the rule does not define the term. Ibid. The court cited guidelines proposed by Loss, 3 Loss 1597, which are "presumably ... the indicia" by which "distribution" is to be 
interpretation of the rule. The motivation for promulgation of 10b-6 was a desire to protect the investing public from losses due to the withdrawal of artificial price supports. ${ }^{85}$ In the Pappas case, the objection of the shareholders was not that they suffered a loss through the creation of an artificial market; rather, relief was requested for damage resulting from corporate mismanagement.80 Further, while a literal reading of $10 \mathrm{~b}-6$ might not preclude application of the prohibition to private transactions, all precedent has developed in relation to market activity. ${ }^{87}$ The investors in Pappas were not required to pay a price determined solely by the give-andtake of a public market vulnerable to hidden manipulation; rather, the price and conditions of the sale were negotiated directly with the issuer. ${ }^{88}$ Thus, the price-raising bidding and purchasing which had previously been the bases of $10 \mathrm{~b}-6$ violations were not at issue. The value of the Pappas case lies in its exemplification of the confusion generated by imprecisely defining the term distribution. Even if some merit is found in the Commission's view that professional broker-dealers can discern sufficient guidelines for the application of 10b-6 from previous cases, recognition must be given to the fact that others who do not share this daily contact with securities transactions

defined; but neither the Loss analysis nor the court's application of it is supported by citation to any decisional authority. See ibid.

${ }^{85}$ See SEC Exchange Act Release No. 5194 (July 5, 1955), reprinted at 20 Fed. Reg. 5075 (1955).

${ }^{80}$ The plaintiffs contended that the defendant members of the board of directors caused the corporation to issue shares at less than true value and falsely represented to the shareholders that the private investors required the directors to purchase a portion of the newly issued shares to show their faith in the stability of the corporation.

In their complaint, the plaintiffs requested no relief under rule $10 \mathrm{~b}-6$ but rather based their assertions on the $10 \mathrm{~b}-5$ prohibition against making any untrue statement of a material fact or omitting to state a material fact and on $\$$ I6 (b) of the Securities Exchange Act which allows recovery by shareholders of any profits made by insiders through misuse of information made available to them by reason of their relationship to the issuer. See Supplemental and Amended Complaint for Civil Action No. 96.62 filed February 14, 1963, Pappas v. Moss, 257 F. Supp. 345 (D.N.J. 1966). Moreover, after the district judge had submitted his opinion with reference to a $10 \mathrm{~b}-6$ violation, both the plantiffs and defendants objected to the application of that rule. See Memorandum in Support of Plaintiff' Motion to Amend and Supplement the Findings and Decision, p. 2, and Brief in Support of Defendants' Motion for Amended Findings, p. 13. While the district judge did grant some of the alterations in the findings and decision requested by the plaintiff, he refused to change his position as to the $10 \mathrm{~b} \cdot 6$ violation. See Supplemental Opinion by Judge Wortendyke, 257 F. Supp. at 368-69.

${ }^{87}$ See, e.g., Theodore A. Landau d/b/a Landau Co., 40 S.E.C. 1119 (1962); Bruns, Nordeman \& Co., 40 S.E.C. 652 (1961).

${ }^{85}$ The purchasers bought the securities for 6 dollars per share while the prevailing market price was approximately 10 dollars per share. 257 F. Supp. at 349. 
will occasionally have to evaluate the relevance of the rule to a particular factual situation. 89

\section{Activities Proscribed}

Actual purchasing. The most obvious violation of rule $10 \mathrm{~b}-6$, which, unlike the other antimanipulation provisions, is addressed only to bidding and purchasing, ${ }^{90}$ involves the actual purchase of the distributed security on a public market. ${ }^{91}$ During the period when the rule was given its first decisional tests, the argument was often made on behalf of the registrant that $10 \mathrm{~b}-6$ was directed solely against those activities which raised the market price and that if purchases or bids were made merely to maintain a steady market during the distribution, the rule could not be the basis of any sanction. ${ }^{92}$ The SEC rejected this argument, asserting that the prohibition of the rule was absolute. ${ }^{93}$ Such an interpretation can be supported by the observation that the rule specifically provides that price supporting must be done in conformity with the provisions of rule $10 \mathrm{~b}-7,{ }^{94}$ which require that potential stabilizing be closed to purchasers and actual stabilizing be reported to the SEG.

Bidding. The prohibition of the rule extends expressly to bidding as well as to purchasing. Even before the rule was adopted, arguments were made that bidding in the National Daily Quotation Sheets should not be held to be manipulative. ${ }^{95}$ Some practitioners felt that since these sheets were distributed only among dealers, the retail investing public was not influenced by them. ${ }^{96}$ With strong support from other authorities, ${ }^{97}$ the SEG has consistently contended

${ }^{80}$ See note 80 supra and accompanying text.

${ }^{\circ}$ See rule 10b-6(a), note 6 supra.

${ }^{21}$ See, e.g., Life Shares Trading Corp., SEC Exchange Act Release No. 7211 (January 8, 1964); C. A. Benson \& Co., SEC Exchange Act Release No. 7044 (March 26, 1963) ; Bruns, Nordeman \& Co., 40 S.E.C. 652 (1961). The prohibition is enforced as stringently when the purchaser affects the existing market, see, e.g., SEC v. GeorgiaPacific Corp., '64'66 CCH FED. SEc. L. REP. 91692 (S.D.N.Y. 1966), as when he, by his purchases and bids, creates the only market in the security, see, e.g., Duval Sec., Inc., SEC Exchange Act Release No. 7655 (July 23, 1965); Theodore A. Landau d/b/a Landau Co., 40 S.E.C. 1119 (1962).

${ }^{02}$ See SEC v. Scott Taylor \& Co., 183 F. Supp. 904, 908 (S.D.N.Y. 1959).

D3 Ibid.

17 C.F.R. $\$ 240.10 \mathrm{~b}-7$ (1964). See 10b-6 (a): "Provided, however, That this section shall not prohibit ... (viii) stabilizing transactions not in violation of $\$ 240.10 \mathrm{~b}-7 . .$. "

${ }^{\circ 5}$ See Halsey, Stuart \& Co., 30 S.E.C. 106, 126 (1949).

${ }^{\circ 0}$ See Barrett \& Co., 9 S.E.C. 319, 325 (1941).

${ }^{97}$ See 3 Loss 1564-65; Bloomenthal, The Case of the Subtle Motive and the Deli- 
that such bidding does affect the public market insofar as it is indicative of a willingness on the part of professionals to trade in the security. Further, it can reasonably be assumed that many brokerdealers recommend a particular security partly upon the basis of its status on the inside market. ${ }^{98}$ Since a broker-dealer was not bound to accept stock offered in response to bids in the inside market, ${ }^{99}$ those who opposed the Commission's view argued that even if the investing public were influenced by the sheets, such bidding was not accepted as a reliable gnide to investor acceptance of a security and should not, therefore, carry the same sanctions as those imposed for manipulative exchange bidding or purchasing. The premise of this argument is contrary not to any formal enactment relative to the enforceability of intra-dealer bidding, but rather to the rules of two organizations which affect all dealers using the sheets. First, the National Quotation Bureau, Inc., publisher of the sheets, includes a clause in the subscription contract which prohibits insincere bidding and which allows for termination of the agreement if an indefinite bid is found.100 Secondly, the National Association of Security Dealers, in its Rules of Fair Practice, provides that no bid is to be made unless the broker-dealer is prepared to respond to an offer if market conditions remain unchanged. ${ }^{101}$

Through the numerous proceedings in which the submission of progressively higher bids in the sheets has been an issue, the Commission has developed two interpretations which represent its view of the relevance of this type of activity. First, it is now well established that no offers need be made by other dealers to meet the bid submitted in order to find a violation of $10 \mathrm{~b}-6 .{ }^{102}$ Further, a registrant cannot defend by demonstrating that many other legitimately

cate Art-Control and Domination in Over-the-Counter Securities Markets, 1960 DuKE L.J. 196, 198-99.

${ }^{88}$ See, e.g., SEC v. Scott Taylor \& Co., 183 F. Supp. 904, 907 n.6 (S.D.N.X. 1959).

"The insertion of bids and offers in the sheets would have the effect of creating an impression of interest and activity and lend support to the price level at which the stock was being distributed, and thus facilitate further such distribution." Sutro Bros. \& Co., SEC Exchange Act Release No. 7053, at 9 n.26 (April 10, 1963).

${ }^{00}$ See Halsey, Stuart \& Co., 30 S.E.C. 106, 126 (1949).

${ }^{100}$ See Special Study, pt. 2, 604. See generally id. at 595-609.

101 Section 6, Rules of Fair Practice, NASD Manual, D-6 (1966). Also prohibited is the submission of a bid for less than the normal unit of trading unless a designation is made on the bid sheet. Policy with Respect to Firmness of Quotations, NASD Manual, G-57 (1966).

${ }^{102}$ See Sidney Tager, SEC Exchange Act Release No. 7368, at 4 (July 14, 1964), aff'd, 344 F.2d 5 (2d Cir. 1965). 
motivated dealers also submitted bids at a similar price level. ${ }^{103}$ This latter argument is often used in support of a contention that the security, often underpriced, was really thought to be worth the amount of the bid. ${ }^{104}$ In the majority of cases, however, the registrant against whom the proceedings are directed has so clearly dominated the market in terms of the percentage of bids submitted that the Commission has had little difficulty discounting the siguificance of bidding by other dealers. ${ }^{105}$

Trading in a similar security. The purchasing of securities which might affect the marketability of the distributed security is also proscribed. The rule explicitly prohibits trading in any security into which the security which is the subject of the distribution might be converted.106 SEC staff policy has long recognized that any enhancement of a junior security tends to make the senior security more appealing insofar as the prospect of a profitable exchange is a major consideration in an evaluation of investment return potential. ${ }^{107}$

In addition, the rule prohibits trading in "any security of the same class and series." 108 The assumption behind this regulation is that, except for first issues, the marketability of a security subject to distribution is largely dependent upon that issue's previous market performance. While the application of the trading prohibition is clear in most cases, some question has been raised as to what factors will be considered in determining whether senior securities with the same rate of return are "of the same series." One situation involved a public utility with several external loan issues outstanding at rates varying up to five per cent, all of which were not covered by a tax to

\footnotetext{
${ }^{103}$ See Shearson, Hammill \& Co., SEC Exchange Act Release No. 7743 (Novemher 12, 1965); J. H. Goddard \& Co., SEC Exchange Act Release No. 7618 (June 4, 1965); Theodore A. Landau d/b/a Landau Co., 40 S.E.C. 1119 (1962). But see Lum, Inc., SEC Securities Act Release No. 4850, at 4 (December 21, 1966), in which the Commission held that bidding hy other broker-dealers was a factor which militated against revocation of a broker-dealer's registration when he was charged with manipulation under $\S 17$ (a) of the Securities Act.

${ }^{104}$ See Gob Shops of America, Inc., 39 S.E.C. 92, 102 (1959); Halsey, Stuart \& Co., 30 S.E.C. 106, I12 (1949).

${ }^{105}$ See, e.g., Shearson, Hammill \& Co., SLC Exchange Act Release No. 7743 (November 12, 1965); J. H. Goddard \& Co., SEC Exchange Act Release No. 7618 (June 4, 1965); Theodore A. Landau d/b/a Landau \& Co., 40 S.E.C. 1119 (1962).

${ }^{106}$ Rule 10b-6 (b); see note 6 supra.

${ }^{107}$ See 3 Loss 1596 \& n.121.

${ }^{108}$ Rule $10 \mathrm{~b}-6$ (a); see note 6 supra.
} 
which a new debenture would be subjected. ${ }^{109}$ Prior to the public bidding to determine the rate of the new issue, a firm requested an opinion as to which of the old issues it should not bid for or purchase, since the firm had reason to believe that tax-exempt institutions holding these securities might wish to dispose of them in favor of the new issue. The SEC staff advised that while the debentures with rates of less than five per cent would probably be distinguishable from the new offering, the broker-dealer should suspend trading in the five per cent debentures, for if an identical rate were established, the staff would consider the new debentures indistinguishable from the outstanding five per cent issue which would mature only eleven months earlier. ${ }^{110}$ Noticeably absent from the Commission's consideration was any reference to the fact that the two issues would be taxed differently to most holders. The inference to be drawn from this omission is that whether securities are of the same series depends not so much on whether they are issued simultaneously but on whether an investor comparing the internal characteristics of the two might consider the securities to be similarly desirable.

Unfortunately, if the Commission intends this ad hoc decision to be indicative of the basis it will employ for future determinations, it has presented an unrealistic criterion insofar as no consideration is afforded the external factor of tax consequences. In his evaluation of the investment potential of the debentures, an investor with even a minimum of market experience would consider the possibility of a tax diminution of his return. A preferable test by which the Commission could have determined whether the securities were "of the same class and series" would have included a consideration of whether, in light of all relevant favors, investors would distinguish the two securities in making an investment decision.

Sales to related and affiliated persons.111 When a distributing

${ }^{100}$ See Letter From Edward H. Emerson, Special Consultant, Securities and Exchange Commission, to Sullivan \& Cromwell, June 11, 1965, at 1 .

$110 \mathrm{Id}$. at 2.

${ }^{11 x}$ Discussions of the applicability of rule $10 \mathrm{~b} \cdot 6$ to sales to related and affiliated persons are often overshadowed by consideration of the more difficult question of what specific types of limitations should be placed upon sales to affiliates. The desirability of limitations upon sales of this type is most strenuously argued with respect to "hot issues"-securities particularly attractive in terms of potential growth and investor demand. See Rotberg, The "Hot Issue," 17 Bus. LAw. 360 (1962). At the heart of the controversy over the extent to which affiliates should be allowed to participate in dis- 
broker-dealer sells a substantial part of an offering to related or affiliated persons, ${ }^{112}$ it might be deemed to have participated in the purchasing and, consequently, to have violated rule $10 \mathrm{~b}-6$. If the account to which the securities are sold is one in which the brokerdealer can be deemed to have a beneficial interest, the consequential

tributions of these issues is a feeling that their purchases unjustly reduce the supply of the security made available to the public. See First California Co., 40 S.E.C. 768, $771-72$ (1961).

While neither the NASD nor the SEC has advocated the most extreme position that affiliates of the distributing broker-dealer can make no purchases of the hot issue, both organizations have issued interpretations which increase the restrictions on a brokerdealer's activities when sales are made to such persons. For example, the SEC requires that the plan of distribution must be disclosed whether the offering necessitates a prospectus or is pursuant to Regulation A. SEC Exchange Act Release No. 6097 (October 23, 1959). If the distributor has a preconceived plan which includes substantial sales to affiliates, this fact must also be disclosed. See R. A. Holman \& Co., SEC Exchange Act Release No. 7770, at 4-5 (December 15, 1965), aff'd, 366 F.2d 446 (2d Cir. 1966); Preferred Securities, Inc., SEC Exchange Act Release No. 7198 (December 13, 1963). The purpose of this disclosure requirement is to alert investors to the fact that only a limited amount of the offering will be distributed publicly and to the possibility that the demand for the securities will significantly affect the market price. Besides this potential failure to make adequate disclosure, a violation of rule $10 \mathrm{~b}-5$ may be found if the offering price were announced at a certain figure when, in fact, purchases made by the public would be made from securities resold by affiliates at a higher price. See Batten \& Co., SEC Exchange Act Release No. 7086 (May 29, 1963), aff'd, 345 F.2d 82 (D.C. Cir. 1964).

The NASD Rules of Fair Practice present a more stringent position: sales to affiliates are absolutely prohibited if the dealer has unfilled orders unless the sales are in accordance with "normal investment practice" and the amount so allocated is "insubstantial and not disproportionate" in terms of the broker-dealer's allotment. In terpretation with Respect to "Free-Riding and Withholding," NASD MANUAL, G-23, -24 (1966). "Normal investment practice" for the purpose of this interpretation is defined to mean the "history of investment in an account with the member. If such history discloses a practice of purchasing mainly 'hot issues,' such record would not constitute a 'normal investment practice' as used in this interpretation. If the account involved is that of the member, such account must be clearly an investment account as distinct from a regular inventory trading account." $I d$. at G-25. See generally L. H. Rothchild \& Co., SEC Exchange Act Release No. 7182 (December 3, 1963). The Commission contemplated the adoption of a rule similar to the NASD's, SEC Exchange Act Release No. 3707 (April I6, 1946), but later decided, consistent with its policy of promoting industry self-regulation, to allow the association to regulate the area. See First California Co., supra, at 771 n.4.

112 For the purposes of the NASD Rules of Fair Practice, the term "affiliate" means "any officer, director, partner, employee or agent of the member or of any other member or . . . a member of the immediate family of any such person." Interpretation with Respect to "Free-Riding and Withholding," NASD MANuAL, G-24 (1966). Sales to persons in most of these classifications would also be scrutinized under the SEC provisions. See R. A. Holman \& Co., SEC Exchange Act Release No. 7770 (December 15, 1965), aff'd, 366 F.2d 446 (2d Cir. 1966) ("immediate family," "close relatives," "secretary for registrant," and "counsel for registrant"); Batten \& Co., SEC Exchange Act Release No. 7086 (May 29, 1963), affd, 345 F.2d 82 (D.C. Cir. 1964) ("relatives, employees, and friends"). 
violation is specifically covered by $10 \mathrm{~b}-6$ (a). ${ }^{113}$ While available precedent presents no definitive analysis of the beneficial interest concept, ${ }^{114}$ apparently the basic determination involves consideration of whether the broker-dealer actually makes the decisions as to when and at what price securities will be sold from the nominal account. ${ }^{115}$ Further, the distributor can be viewed as an aider and abettor to a 10b-6 violation if he sells part of the offering to an affiliate's account or to an account of another broker-dealer ${ }^{116}$ with the intention that the purchaser will create an independent market in the security. ${ }^{117}$ In order to sustain a charge of concerted purpose against a nondistributing broker-dealer, however, the Commission must overcome an obvious evidentiary difficulty, for there is no prohibition against an independent dealer buying securities distributed by another member of the industry. ${ }^{118}$ Finally, in the case of a sale to an affiliate, repurchases by the broker-dealer may give rise to a ruling that the distribution had not been completed until these reacquired shares had come to rest in the hands of the public. ${ }^{110}$ Thus, the repurchases, having been made during the course of a distribution, will be in violation of $10 \mathrm{~b}-6 .{ }^{120}$

\footnotetext{
${ }^{128}$ See note 6 supra.

${ }^{11}$ See generally Duval Securities, Inc., SEC Exchange Act Release No. 7655 (July 23, 1965); R. Baruch \& Co., SEC Exchange Act Release No. 7138 (September 11, 1963), supplemented by, SEC Exchange Act Release No. 7932 (August 9, 1966); Preferred Securities, Inc., SEC Exchange Act Release No. 7198 (December 13, 1963); Best \& Garey Co., SEC Exchange Act Release No. 6841 (July 6, 1962); Batten \& Co., 40 S.E.C. 997 (1962); First California Co., 40 S.E.C. 768 (1961).

Without analyzing the concept of beneficial interest in detail, the Commission held in Preferred Securities, Inc. that sales to a corporation wbolly-owned or fifty per centowned by a distributing broker-dealer may be deemed to be sales to an account in which he has a beneficial interest. SEC Exchange Act Release No. 7198 (December 13, 1963).

${ }^{115}$ Cf. Batten \& Co., 40 S.E.C. 997 (1962).

120 If sales are made to a broker-dealer outside of the distributing firm, the size of the purchase may be so substantial as to qualify this outside trader as an underwriter of the distribution. If such a finding were made, the broker-dealer registration of the undesignated underwriter would be subject to suspension or revocation for his failure to register with the syndicate. SEC Exchange Act Release No. 6097 (October 23, 1959).

${ }^{117}$ See Lewisohn Copper Corp., 38 S.E.C. 226 (1958); cf. Hayden Lynch \& Co., SEG Exchange Act Release No. 7935 (August 10, 1966).

${ }^{118}$ See Sidney Tager, SEC Exchange Act Release No. 7368, at 5-6 (July 14, 1964), aff'd, 344 F.2d 5 (2d Cir. 1965).

${ }_{110}$ SEC Exchange Act Release No. 6097 (October 23, 1959); see R. A. Holman \& Co., SEC Exchange Act Release No. 7770 (December 15, 1965), aff'd, 366 F.2d 446 (2d Gir. 1966); Batten \& Co., SEC Exchange Act Release No. 7086 (May 29, 1963), aff'd, 345 F.2d 82 (D.C. Cir. 1964).

120 Mayo \& Co., SEC Exchange Act Release No. 7310, at 3 (May 8, 1964).
} 
Emphasis should be given to the Commission's position that sales to affiliates are not improper per se and that a violation of $10 \mathrm{~b}-6$ results only when the distributing broker-dealer is implicated in a manipulative scheme involving such sales. ${ }^{121}$ Similarly, the Commission does not contend that a broker-dealer may never repurchase from an affiliate's account. Although the Commission has never clearly defined the prohibition period for these repurchases, they certainly will not be allowed prior to the closing of the distribution ${ }^{122}$ and presumably will be prohibited until the market for the security has become sufficiently independent of the effect of the distribution.

Corporation's purchase of its own securities. The Georgia-Pacific litigation ${ }^{123}$ demonstrates the SEC's position that purcbases by a corporation of its own shares must conform to the limitations of $10 \mathrm{~b}-6$. In that case, the defendant company was engaged in acquiring several other corporations under stock exchange programs. With regard to some of the acquired firms, the amount of stock which Georgia-Pacific would have to relinquish was, by the acquisition agreements, dependent upon the closing market price of GeorgiaPacific stock during certain valuation periods. In its complaint, the SEC charged that purchases were made for employee stock bonus plans and for the accounts of corporate shareholders in a manner which raised the price of Georgia-Pacific stock "in order that GP's obligation to issue additional shares . . . would be avoided or reduced."124 The defendants, including the corporation and three of its shareholders, two of whom were trustees for the stock bonus trusts,

${ }^{121}$ Rather than absolutely prohibiting sales to and repurchases from affiliates, the SEC has indicated that it will scrutinize this type of transaction for indications of a preconceived plan. See SEC Exchange Act Release No. 6097 (October 23, 1959). The use of circumstantial evidence will be a significant factor in the determination that a preconceived plan for repurchasing existed. For example, in reaching its conclusion in $R$. A. Holman \& Co. that "a substantial portion of the . . offering was sold to insiders and 'affiliated' persons with a view to its subsequent repurchase and distribution," the Commission considered "the expected public salability of the . . stock, registrant's short sales, the relationship of the purchasers to registrant or Holman, [and] . . the period of retention of the stock by purchasers ..." SEC Exchange Act Release No. 7770, at 4 (December 15, 1965), aff'd, 366 F.2d 446 (2d Cir. 1966).

${ }^{122}$ See R. A. Holman \& Co., SEC Exchange Act Release No. 7770, at 4 (December 15, 1965), aff'd, 366 F.2d 446 (2d Cir. 1966); Advanced Research Associates, Inc., SEC Exchange Act Release No. 7117, at 20-22 (August 16, 1963).

${ }^{123}$ SEC v. Georgia-Pacific Corp., '64-'66 CCH FED. SEC. L. REP. $\$ 91692$ (S.D.N.Y. 1966).

${ }^{124}$ Excerpts from the Complaint are reprinted $i d$. at 91680 . See generally SEC Litigation Release No. 3496 (April 27, 1966). 
consented to a judgment which outlined the circumstances under which future purchases were to be made for personal investment, for the trust, and for acquisition of treasury shares for future exchanges. The final order established that when the defendant corporation begins serious negotiations looking toward acquisition of another firm, the latter must be advised of any market activity by GeorgiaPacific, its stock plan, or the noncorporate defendants in the previous thirty days. ${ }^{125}$ The company is required to elicit similar information from all of its officers, directors, and holders of more than ten per cent of its shares. Further, the defendants are absolutely prohibited from bidding and purchasing ${ }^{126}$ while the corporation is distributing securities or during the period when the terms of an acquisition agreement with another firm are being finally established.127 With respect to all other times, limitations are placed upon the volume acquisitions and the conditions under which shares can be purchased.

The restrictions imposed upon purchases by the acquiring corporation and its major shareholders seem to be justified insofar as the interest of these groups in the success of the exchange or distribution could motivate a manipulative intervention into the market. Prior practice is consistent with this limitation, for $10 \mathrm{~b}-6$ specifically proscribes purchases by issuers, and staff policy has included officers, directors, and controlling persons within this concept. ${ }^{128}$ Moreover, the limitations upon purchases by the corporation for the acquisition of treasury shares to be used in an exchange would appear to temper the adverse effect which such a concentration of demand would have upon the market.

The SEC's position concerning the applicability of $10 \mathrm{~b}-6$ to purchases for employee stock plans is less clear than that taken in relation to purchases for the accounts of the corporation and its officers and directors. In previous instances, the Commission has required that purchases by such a plan cease when a distribution is actually in

${ }^{125}$ See '64-'66 CCH FED. SEC. L. REP. ๆ 91692. See generally SEC Litigation Release No. 3511 (May 23, 1966).

${ }^{120}$ While the defendants who were trustees for the Stock Bonus Trust were prohibited from purchasing securities for the trust, provision was made in the final judgment for appointment of an independent corporate fiduciary who would be allowed to continue purchasing during distributions and exchanges. See text accompanying note 132 infra.

127 '64-'66 CCH FED. SEC. L. REP. ๆ 91692.

${ }^{128}$ See 3 Loss 1599 n.133; Foshay, Market Activities of Participants in Securities Distributions, 45 VA. L. REv. 907, 935 (1959). 
progress. ${ }^{129}$ This position is most likely to be taken when the person in charge of the plan is also in some position of control within the corporation. ${ }^{130}$ On the other hand, the SEC staff has stated that it will not place limitations upon the purchases of an employee stock plan where administration of the plan is guided by an independent trustee "who has full discretion as to time and price" of purchases. ${ }^{131}$ However, in the Georgia-Pacific case, the final judgment provided that future purchases for the plan were to be made under a unique arrangement. The original trustees of the Georgia-Pacific plan, who were not independent of the control of the corporation, were retained but prohibited from purchasing for the plan except through an independent corporate fiduciary. While the independent agent was allowed to make purchases irrespective of the occurrence of an exchange or distribution, he was permitted to place orders with only one broker per day and to purchase only ten per cent of the average weekly trading volume in specified Georgia-Pacific securities. No bid or purchase was to be made at the opening of the exchange or within one hour of its closing or at a price in excess of that currently prevailing. ${ }^{132}$

One consideration which militates against imposition of any

120 Foshay, supra note 128, at 934-37.

Foshay notes at least three situations in which purchases were to be disconitinued by the employee stock plans of companies which were involved in distribution. However, except in one instance, no limitations were placed upon the plans during nondistribution periods. Also, Foshay indicates that purchases by stock plans were, not curtailed when the distribution originated from a foundation connected with the issuer: Since the stock plans of General Motors and Ford Motor Company were not prohibited from trading while the Sloan and Ford Foundations respectively were undertaking to dispose of large holdings of securities, Foshay concludes that the foundations were viewed as entities separate and distinct from the corporation. Id. at 935.

${ }^{130}$ The Genesco, Inc. Prospectus of May 10, 1966, outlines limitations which that corporation voluntary imposed upon purchases by its employee stock plans after warnings by the SEC. The limitations imposed are similar to those enforced in the GeorgiaPacific litigation. See '64-'66 CGH FED. SEC. L. REP. I 77354; note 132 infra and accompanying text. As in Georgia-Pacific, purchases for the plans were made by persons who were in a position to exercise control over the corporations. The chairman of the board of directors of Genesco, Inc. was the trustee under two employee stock purchase plans. Other officers and directors of the corporation were the trustees of a third plan.

${ }_{181}$ See Memorandum to Clients by Sullivan \& Cromwell, p. 13, May 12, 1966. Apparently, the staff had not always granted full discretion to independent trustees, for in 1959 when the Ford Foundation undertook a secondary offering of common stock of the Ford Motor Company, the independent trustee for the Company's stock plan was subjected to limitations upon its volume of purchases and methods of acquisition. However, the prohibition was not absolute. See Foshay, supra note 128, at 935-36. ${ }^{132}$ See '64-'66 CCH Fed. SEc. L. REP. I 91692. 
limitation upon purchases by an employee stock plan is the possibility that the employees will be deprived of the full benefit of the program. ${ }^{133}$ Restrictions on purchasing are especially difficult to justify in relation to plans which dispense acquired securities directly to employees, for the extent to which employees holding small amounts of their employer's securities would be motivated to upset the competitive nature of the market is minimal. Further, if the SEC continues to prohibit some plans from purchasing when a distribution is in progress, several difficulties will arise. If the plan has been making regular purchases of an appreciable number of shares, ${ }^{134}$ withdrawal of this demand would tend to accentuate the oversupply of the market which characteristically occurs in many distributions. If because of the oversupply the financing of the corporation were impaired, assuming the distribution is made on behalf of the issuer, the stock plan would have adversely affected the interests of the corporation as well as the participating employees. Also, when a distribution in the sense of a major selling effort by a broker-dealer is undertaken, those in charge of the stock plan are likely to be unaware of its occurrence. Imposition of sanctions for purchases made during this period would be unjust without the SEC's requiring that improved publicity be given these secondary distributions. ${ }^{135}$ Where the individual directing the plan is also in

\footnotetext{
${ }^{133}$ See Foshay, supra note 128 , at 933 .

To relate the volume of allowable purchases by a stock plan to the volume of trading by all investors, as was done in the Georgia-Pacific and Genesco situations, is to assume that the degree of employee interest in the employer's securities bears a direct relationship to the interest which members of the general investing public have in the stock. Such an assumption is questionable since the basis of motivation for purchasing stock in a company may differ between employees and other investors. For example, the latter group probably pays much attention to the potential of the general industry in which the employer's firm functions while the former group will consider mainly the operation of the particular plant. Consequently, if in a particular period employec interest in the employer's security is at a high level, a low interest among outside investors will prevent complete satisfaction of any desire employees might have to purchase the security.

134 Foshay notes that, in 1954, purchases for General Motors' stock plan represented approximately $16 \%$ of all G.M. shares traded on the New York Stock Exchange. The trustee of the Ford stock plan made purchases representing $18 \%$ of the total exchange trading volume in Ford stock in 1956; for 1957 and 1958, the trustee bought $21 \%$ and $19 \%$ respectively of the total trading volume. Foshay, supra note 128 , at 934,936 .

${ }^{135}$ The inference to be drawn from the current policies behind regulation of unregistered secondary distributions is that application of $10 \mathrm{~b}-6$ to these situations is intended only to curb the market activities of broker-dealers. No indication has been given that an issuer will be prosecuted for an inadvertent bid or purchase during such an offering. Yet, since such purchases would be prohibited under a literal application
} 
some position of control with respect to the company, however, the possibility of manipulative purchases is clear, and the prohibition on purchasing can logically be extended to encompass the market activities of this type of director. Nevertheless, in order to ensure that the employee-beneficiaries receive the full benefit of the program and that no additional market over-supply occurs, the Commission could exempt all employee plans from the prohibitions of $10 \mathrm{~b}-6$, including those directed by a controlling person, and attack any attempted manipulation with other provisions of the 1933 and 1934 Acts. ${ }^{136}$

While some support can be found for the SEG's attitude toward employee stock plans directed by a controlling person, the restrictions imposed by the consent judgment in the Georgia-Pacific litigation seem less justifiable. Basically, insufficient consideration has been afforded the independent nature of the corporate fiduciary to be appointed by the trustees of the plan. It is difficult to reconcile the lack of discretion accorded this agent with the staff's statement that no limitations will be imposed upon a trustee independent of the control of the company. If a fiduciary is truly independent, a conceptual difficulty arises when his purchases are included under the prohibition on trading by issuers. Further, if the appointee is not related to the management functions of Georgia-Pacific, his status seems to be similar to that of any customer with a substantial investment portfolio. Placing a ceiling upon the volume of purchases by such an investor is without convincing precedent. ${ }^{137}$

In general, what is needed is a complete clarification by the SEC of its present position with regard to purchases by an employee stock plan during a distribution or negotiations for an exchange. This is not to suggest that one simple rule might be suitable in all cases. Any pronouncement would necessarily have to consider the myriad forms which a stock plan might take. Nonetheless, basic discrepancies such as those relating to the discretion to be exercised by an independent trustee and the role of the controlling person as director of a plan could be resolved. Also, guidelines should be established for stock plans which purchase securities not traded on a national

of the rule, a statement from the SEC as to the precise status of purchases of this type would he appropriate.

${ }_{136}$ See note 9 supra.

${ }^{107}$ But see note 134 supra. 
exchange. Since the Georgia-Pacific limitations relate mainly to purchases on an exchange, most of them are not adaptable to the over-the-counter market in which no record is kept of the volume of shares traded and neither opening nor closing bids are entered. Consequently, instead of adopting a limitation phrased in terms of a percentage of trading volume, the permissible volume would need to be expressed as an absolute number of shares. Presumably retained in principle would be restrictions such as the requirement that purchases be made through only one broker and that no bids or purchases be made so as to create actual or apparent active trading. ${ }^{138}$

\section{Those to Whom Rule 10B-6 Applies}

Statutory classifications. Prior to $10 \mathrm{~b}-6, \mathrm{SEC}$ policy apparently restricted the market activities of the syndicate manager more than those of the other members of the underwriting group. ${ }^{130}$ In its current form, however, the rule does not distinguish between these two groups, but rather uses the term underwriter to encompass both. ${ }^{40}$ Rule $10 \mathrm{~b}-6$ (c) (1) defines underwriter in terms of a relationship directly with an "issuer or other person on whose behalf such a distribution is made." 141 While the rule contemplates that the relationship be represented by an agreement, judicial interpretation establishes that even an extremely informal arrangement will suffice. For example, in Shearson, Hammill \& Co., ${ }^{142}$ a dealer's relationship with an issuer qualified under the rule despite the fact that no under-

\footnotetext{
${ }^{238}$ See Memorandum to Clients by Sullivan \& Cromwell, pp. 7-8, May 12, 1966.

${ }^{139}$ See 3 Loss 1595 . Generally, the manager was to withdraw from trading earlier than the other underwriters.

"140."Prospective underwriters" must conform to the same restrictions as underwriters. See ruile 10b-6 (a) (1). A member of the former group is one who has "agreed to submit or has submitted a bid to become an underwriter" or "who has reached an understanding, "with the issuer ...., that he will become an underwriter." Rule $10 \mathrm{~b} \cdot 6(\mathrm{c})(2)$.

${ }_{141}$ Rule 10b-6 (a) (2).

Section 2(11) of the Securities Act, 48 Stat. 74, as amended, 15 U.S.C. $\$ 77$ (b) (11) (1964), also defines "underwriter," but for the purpose of determining whether particular securities should be registered to ensure that proper disclosure of relevant information is made to investors. This definition is more narrow than that found in $10 \mathrm{~b} \cdot 6$ (c), since the formër contemplates an actual agreement with the issuer, while for $10 \mathrm{~b} \cdot 6$ purposes one has merely to submit a bid to underwrite an offering to come within the prohibition of the rule. Nonetheless, $\$ 2$ (II) has been employed in determining whether's a 'particular broker-dealer's activities fall within the prohibition of rule 10b-6. See R. Baruch \& Co., SEG Exchange Act Release No. 7932 (August 9, 1966); Sutro Bros: \& Co., SEC Exchange Act Release No. 7053, at 7 (April 10, 1963).

${ }_{142}$ SEC Exchange Act Release No. 7743 (November 12, 1965).
} 
writing fee was paid and the New York office of the firm had refused to underwrite the issue. ${ }^{143}$ In another case, it was held that the registrant should have inquired into the ownership of the stock he sold and the circumstances of its acquisition; $;^{144}$ a failure to do so when relevant facts would have prompted an investigation by a reasonable man may lead to the revocation of a broker-dealer's registration. ${ }^{145}$ Furthermore, the liability of an underwriter may be indirect even if his relationship with the issuer is formal, for the SEC has determined that, as a matter of law, all the members of an underwriting syndicate are liable if the managing underwriter, who acts as agent for the others, effects unjawful transactions. ${ }^{146}$

As stated above, ${ }^{147}$ the $10 \mathrm{~b}-6$ prohibition applies to the "issuer or other person on whose behalf. [the] ... distribution is being made." Shortly after promulgation of the rule, a proposal was made to amend 10b-6 (a) (2) to make it clear that officers and directors were included within the prohibition. ${ }^{148}$ Though the wording of this announcement was interpreted to mean that staff policy had always assumed these classes were included, ${ }^{149}$ the proposed amendment was withdrawn nine years later. ${ }^{150}$ Even without a formal provision, however, the SEC has continued to extend the prohibition to these classes with apparent acceptance by the courts. ${ }^{151}$

The final category of those prohibited from bidding and purchasing during the course of a distribution include "a broker, dealer, or other person who has agreed to participate or is participating in

$143 \mathrm{Id}$, at 3-7. In Shearson, Hammill \& Co., a few staff members of one of registrant's branch offices undertook to promote sales of securities of an issuer without any formal underwriting agreement with the latter. Similarly, in Lum's, Inc., SEC Secuxities Act Release No. 4850, at 7 (December 21, 1966), the broker-dealer argued that "it had not entered into any agreement and had no obligation to sell [its client's securities] . . ." and that "it received no special undexwriter's fees, commissions or compensation in connection with [the sales it made]." The Commission was persuaded by neither of these arguments and concluded that "for the purpose of Rule I0b-6 the lack of an express arrangement characterized as an underwriting agreement is not controlling." $I d$. at 8.

344 Sutro Bros. \& Co., SEC Exchange Act Release No. 7058, at 10 (April 10, 1963).

245 See ibid.

140 See Opinion of Director of the Trading and Exchange Division, SEC Exchange Act Release No. 3505 (November 16, 1943).

${ }^{147}$ See note 128 supra and accompanying text.

${ }^{148}$ SEC Exchange Act Release No. 5415 (December 5, 1956).

${ }^{140}$ See 3 Loss 1599 n.133. But see Foshay, supra note 128, at 926.

${ }^{260}$ SEC Exchange Act Release No. 7517 (January 22, 1965).

${ }^{25 x}$ See SEC v. Georgia-Pacific Corp., '64-'66 CCH FED. SEC. L. REP. I 91692 (S.D.N.X. 1966). 
such a distribution."152 Decisions interpreting the scope of this phrase have required that an evaluation of the circumstantial evidence indicate that an individual "must have known" that the securities with which he dealt were the subject of a distribution. In the usual case a broker-dealer is found either to have assisted an issuer directly in disposing of an unregistered offering ${ }^{163}$ or, more frequently, to have lent support to the efforts of a distributing brokerdealer. ${ }^{154}$ It must be emphasized, however, that not all brokerdealers are prohibited from buying a security which is the subject of a distribution. ${ }^{165}$ Rather, the primary issue is whether the dealer in question and the issuer or actual distributor are so closely involved that the affiliate is promoting the latter's efforts to market a security. To sustain a finding that the trader probably was or should have been aware of the special nature of the security he bid for or purchased, the Commission will generally determine one or more of the following: (1) the broker-dealer knew that the security had been the subject of a distribution during a recent period; ${ }^{158}$ (2) the brokerdealer had been asked to place bids on behalf of an issuer or distributor whom the former knew held a long position in the security; ${ }^{15 T}$ (3) the relationship between the broker-dealer and the distributor or issuer had been so close that the former's denial of knowledge is unreasonable; ${ }^{158}$ (4) the broker-dealer was aware that quotations in the bid sheets were advancing significantly despite the absence of any demand for the security; ${ }^{150}(5)$ in the case of a security

\footnotetext{
${ }^{162}$ Rule 10b-6 (a) (3). Members of the underwriting group are also broker-dealers, but apparently in order to encompass members of the selling group within the rule's prohibition, clause (a) (3) designates broker-dealers as a class distinct from underwriters.

${ }^{163}$ See R. Baruch \&: Co., SEC Exchange Act Release No. 7138 (September 11, 1963), supplemented by, SEC Exchange Act Release No. 7932 (Augnst 9, 1966); Sutro Bros. \& Co., SEC Exchange Act Release No. 7053 (April 10, 1963).

${ }^{154}$ See, e.g., F. S. Johns \& Co., SEC Exchange Act Release No. 7972 (October 10, 1966), aff'd sub nom. Dlugash d/b/a Douglas Enterprises v. SEC, 373 F.2d 107 (2d Cir. 1967); Sidney Tager, SEC Exchange Act Release No. 7368 (July 14, 1964), aff'd, 344 F.2d 5 (2d Cir. 1965); Theodore A. Landau d/b/a Landau Co., 40 S.E.C. 1119 (1962). ${ }^{155}$ See Sidney Tager, supra note 154.

${ }^{158}$ See R. Baruch \& Co., SEC Exchange Act Release No. 7932, at 4 (August 9, 1966); Sidney Tager, SEC Exchange Act Release No. 7368, at 5 (July 14, 1964), aff'd, 344 F.2d 5 (2d Cir. 1965).

${ }_{167}$ See F. S. Johns \& Co., SEC Exchange Act Release No. 7972 (October 10, 1966), aff'd sub nom. Dlugash $\mathrm{d} / \mathrm{b} / \mathrm{a}$ Douglas Enterprises v. SEC, 373 F.2d 107 (2d Gir. 1967). ${ }^{168}$ See Theodore A. Landau d/b/a Landau Co., 40 S.E.C. 1119 (1962).

${ }^{150}$ See F. S. Johns \& Co., SEC Exchange Act Release No. 7972 (October 10, 1966), aff'd sub nom. Dlugash $\mathrm{d} / \mathrm{b} / \mathrm{a}$ Douglas Enterprises v. SEC, 373 F.2d 107 (2d Gir. 1967).
} 
the price of which had been substantially increased by manipulative activity, the broker-dealer had previously dealt with the stock at a lower price. ${ }^{100}$ In defense of a charge that he should have been cognizant that particular securities were subject to $10 \mathrm{~b}-6$ restrictions, the broker-dealer is not assisted by the fact that he received assurances from the primary distributor that the stock was free to trade if it is found that, under the circumstances, the registrant should have taken "reasonable precautions to satisfy [himself] that the distribution was over."161

The implications of a finding that an individual must have known of another's activities are especially significant in the relationship between a broker-dealer and the salesmen he employs. For example, a suspension or revocation of a broker-dealer's registration may result from his failure to investigate and correct unusual and questionable circumstances surrounding the activities of his employees. ${ }^{162}$ Management is responsible for correctly interpreting "warning signals" and for taking appropriate action to rectify employee shortcomings. ${ }^{103}$ While the Commission has never under-

${ }^{100}$ See Theodore A. Landau d/b/a Landau Co., 40 S.E.C. 1119, 1124 (1962).

${ }^{101}$ Sidney Tager, SEC Exchange Act Release No. 7368, at 5 (July 14, 1964), aff'd, 344 F.2d 5 (2d Cir. 1965).

102 Broker-dealers are charged with the responsibility for supervising all activities of their employees and not merely those which would violate 10b-6. See Special Study, pt. 1, 290-91. This obligation, developed through Commission rulings, has now been proposed in regulatory form to apply to broker-dealers who market over-the-counter but who are not members of the NASD. See SEC Exchange Act Release No. 7984 (October 25, 1966). Those who are members of the NASD apparently must observe similar standards. See Reuben Rose \& Co., SEC Exchange Act Release No. 7964 (September 29, 1966). In Reynolds \& Co., SEC Exchange Act Release No. 6273, at 14-15 (May 25, 1960), the SEC outlined its position as follows: "[W] here the failure of a securities firm and its responsible personnel to maintain and diligently enforce a proper system of supervision and internal control results in the perpetuation of fraud upon customers or in other misconduct in willful violation of the Securities Act or the Exchange Act, for purposes of applying the sanctions provided under the securities laws such failure constitutes participation in such misconduct, and willful violations are committed not only by the person who performed the misconduct but also by those who did not properly perform their duty to prevent it."

${ }^{103}$ See Kamen \& Co., SEC Exchange Act Release No. 7965 (September 29, 1966); Shearson, Hammill \& Co., SEC Exchange Act Release No. 7743, at 25-30 (November 12, 1965); cf. Foshay, supra note 128, at 911; Reuben Rose \&: Co., SEC Exchange Act Release No. 7964 (September 29, 1966).

In one case, the SEC implied that the employer's liability for violation by employees was absolute and not dependent upon a finding of inadequate supervision. Sutro Bros. \& Co., SEC Exchange Act Release No. 7053 (April 10, 1963). The Commission stated: "Registrant as a firm can only act through its employees and agents, and the willful violations of its employees in the course of their employment must be considered the willful violations of the firm." $I d$. at 9 . 
taken to define the precise nature of these signals, an employer presumably should watch for activities such as large volume transactions by his salesmen, excessive activity in one security by an employee when the brokerage firm is not conducting a formalized selling campaign in that security, and unusually close dealing between the salesman and a customer with large holdings in particular securities. ${ }^{104}$ Of course, the salesman is held to knowledge of the distributions which his firm undertakes. ${ }^{165}$ While an offering is being made, the salesman is prohibited from trading even if he is not actively engaged in the firm's efforts to distribute the security. ${ }^{160}$ One foreseeable problem area could develop when a broker-dealer with a large sales force is undertaking an unregistered distribution in the sense of a "major selling effort." Special care must necessarily be exercised to ensure that all salesmen are informed of such an undertaking, so that bidding and purchasing are brought into conformity with the limitations of rule $10 \mathrm{~b}-6$.

Indirect participants. Even if he has not made purchases or placed bids himself, an individual may be found to have violated the rule. The most frequently litigated example of indirect purchasing involves a distributor who has another broker-dealer enter bids for him. ${ }^{107}$ As has been noted in relation to other aspects of 10b-6 enforcement, the failure to find a formal agreement or active collusion does not prevent imposition of sanctions by the SEC. ${ }^{108}$ Furthermore, the party who actually enters the bid may be found to be guilty as a principal for aiding and abetting a 10b-6 violation even though he is not directly or formally involved in the distribution of the security. ${ }^{160}$ Frequently, it is in this situation that the Commis-

\footnotetext{
${ }^{164}$ Cf. SEC Exchange Act Release No. 7984 (October 25, 1966). 1966).

${ }^{105}$ See R. Baruch \& Co., SEC Exchange Act Release No. 7932, at 3.5 (August 9,

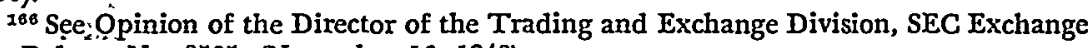
Act Release No. 3505 (November 16, 1943).

${ }^{107}$.See; e.g., SEC v. Scott Taylor \& Co., 183 F. Supp. 904 (S.D.N.Y. 1959); F. S. Johns \& Co., SEC.Exchange Act Release No. 7972 (October 10, 1966), aff'd sub nom. Dlugash d/b/a Douglas Enterprises v. SEC, 373 F.2d 107 (2d Cir. 1967); Sidney Tager, SEC Exchange Act Release No. 7368 (July 14, 1964), aff'd, 344 F.2d 5 (2d Cir. 1965); R. Baruch \& Co.; SEC Exchange Act Release No. 7138 (September 11, 1963), supplemented by, SEG Exichange Act Release No. 7932 (August 9, 1966).

${ }^{108}$ See notes 48.50 supra and accompanying text.

; ${ }^{109}$ See R. Baruch \& Co., SEC Exchange Act Release No. 7932, at 5 (August 9, 1966); Sidney Tager, SEC Exchange Act Release No. 7368 (July 14, 1964), aff'd, 344 F.2d 5 (2d Cir. 1965). The usual sanction imposed as a result of a finding of indirect
} 
sion concludes, on the basis of circumstantial evidence, that a brokerdealer "must have known" of the special relationship the other individual bore to the securities involved.

Foreign underwriters. Because the jurisidction of the SEC under rule $10 \mathrm{~b}-6$ is limited to transactions involving use of the mails, instrumentalities of interstate commerce, or facilities of a national exchange, ${ }^{170}$ many activities in distributions jointly undertaken by American and foreign underwriters-such as purchasing on a foreign exchange by a foreign underwriter-do not come within the direct control of the Commission. ${ }^{171}$ Yet, a broker-dealer in the United States may be found to be an indirect participant in overseas violations; thus, the Agreement among Underwriters often includes some trading restrictions similar to those imposed by $10 \mathrm{~b}-6 .^{172}$ Requests for such inclusions are made even in the most extreme situation where the offering is made entirely outside of this country and not registered under the Securities Act. ${ }^{173}$ However, these restrictions often do not interfere with the normal procedure on many foreign exchanges which allows an underwriter to continue normal trading activity despite his involvement in the distribution. ${ }^{174}$ Even when the Agreement among Underwriters does not suspend the trading

participation in the distribution is revocation or suspension of the broker-dealer's registration.

${ }_{170}$ Rule 10b-6 (a); see note 6 supra.

${ }^{171}$ See generally Wordd Community Assoctation, International Financing and INVESTMENT 452-60 (McDaniels ed. 1964).

Provision was made in the Exchange Act to equip the Commission with the means to control manipulation on a foreign exchange by a broker-dealer registered in this country. Section 30 (a) of that act provides: "It shall be unlawful for any broker or dealer, directly or indirectly, to make use of the mails or of any means or instrumentality of interstate commerce for the purpose of effecting on an exchange not within or subject to the jurisdiction of the United States, any transactions in any security the issuer of which is a resident of, or is organized under the laws of, or has its principal place of business in, a place within or subject to the jurisdiction of the United States, in contravention of such rules and regulations as the Commission may prescribe as necessary or appropriate in the public interest or for the protection of investors or to prevent the evasion of this title." 48 Stat. 904, 15 U.S.C. $\$ 78 \mathrm{dd}$ (a) (1964). However, the Commission has no rules or regulations in force under this title. Consequently, since the section is not self-operative, it is without current significance in controlling the activities of a broker-dealer on a foreigu exchange.

${ }^{172}$ See Memorandum on Application of SEC Rules 10b-6, 10b-7 and 10b-8 to Foreigu Offerings, February 7,1966 , at $2-3$, in the files of Sullivan \& Cromwell.

${ }^{173} I d$. at 9-10.

${ }^{176}$ In practice, firms in this country frequently request disclosure in the prospectus if the foreign underwriters are to be allowed to continue their normal trading activities. Id. at 10-11. The law firm notes that it is desirable to obtain a "no action" letter from the Commission to ensure that the offering cau be made without interruption. 
activity of the foreign underwriters, the Commission has granted exemptions when such transactions would not cause undue interference with the distribution. ${ }^{175}$

\section{Period of Prohibition}

Commencement of the prohibition. Rule $10 \mathrm{~b}-6$ as finally promulgated included an attempt to specify the commencement of the period during which trading on the market was prohibited. ${ }^{176} \mathrm{Un}$ fortunately, the provisions of the rule are presented with varying degrees of clarity. For example, as to underwriters and prospective underwriters, the general requirement is that the prohibition must begin when a broker-dealer attains the status of either of these groups in relation to a particular distribution..$^{177}$ Yet, the effect of this general statement is largely altered by the exemption in $10 \mathrm{~b}-6$ (a) (xi) which permits bids and purchases not involving the use of facilities of a national exchange to be made up to ten business days prior to the effective date of the registration statement or, in the case

${ }^{175}$ Cohen \& Throop, Investment of Private Capital in Foreign Securities, in A Lawyer's Guide to International Business Transactions 570 (ABA-ALI 1963). "In considering these requests, the Commission is primarily concerned with the impact of the market activities abroad on the United States distribution. In attempting to analyze this impact prior to the commencement of the distribution, all pertinent factors are considered, including the amount of trading activity in the United States, the location of the principal markets, the nature of the distribution, the proposed market activities of United States and European underwriters, and the differences in trading hours between the United States and foreign markets." Id. at 570-71.

${ }^{176}$ Even prior to the first proposal of the rule it was common practice for some broker-dealers to reduce their trading activities when a distribution was contemplated, although much of the tapering off was largely a reaction to the uncertainty as to what constituted excessive trading under then current SEC pronouncements. Sce 3 Loss 1595; Foshay, supra note 128, at 910-11. See generally Opinion of the Director of the Trading and Exchange Division, SEC Exchange Act Release No. 3505 (November 16, 1943). The extent of the adjustment varied among traders with primary consideration given to such factors as the interval between any proposed trading and the offering, the amount of the particular broker-dealer's interest in the offering, and the volume of trading contemplated in relation to the size of the offering. See Foshay, supra note 128 , at 912 , n.18. In general, the managing underwriter began limiting his trading activity when he learned about his participation in the distribution. Other members of the syndicate apparently did not limit their trading to any great extent until the registration statement was filed. See 3 Loss 1595 . Whether members of the selling group curtailed their activities is not clear (see Letter From David V. Stern, Jr., Schumacher, Gilmore, Van Ness \& Stern, to the Securities and Exchange Commission, June 18,1954 ) though the activity of these individuals was probably regulated by agreement with the underwriters.

${ }^{177}$ The earliest possible commencement of the prohibition occurs when the underwriting syndicate is chosen by competitive bidding, for here a broker-dealer becomes an underwriter as soon as he has agreed to submit a bid with a syndicate. Rulc 10b-6 (c) (2); see note 6 supra. But see notes 187-88 infra and accompanying text. 
of an unregistered offering, ten days prior to the commencement of the distribution. Moreover, between the ninth and fifth business days, unsolicited purchases are allowed. ${ }^{178} \mathrm{~A}$ broker-dealer who is connected with the distribution but who is not an underwriter similarly qualifies for the exemption.

Trading prior to the ten-day cushion period must conform to two practical limitations. First, the extension of trading time allowed by the exemption is granted only "if none of the purchases or bids are for the purpose of creating actual, or apparent, active trading or in raising the price" of the distributed security. ${ }^{179}$ By implication, then, the exemption was meant to preserve the continuity of only normal trading activity ${ }^{180}$ and not to allow the broker-dealer actively to facilitate the distribution by injecting an appearance of excessive demand into the market. Second, the practice of the SEC staff has been to extend the ten-day period to permit "cooling off" if activity has been excessive prior to the beginning of the prohibition period. ${ }^{181}$

With respect to an "issuer or other person on whose behalf such a distribution is made," the rule does not specify the point at which its application commences. One inference drawn from the absence of any guidelines is that an issuer must cease bidding and purchasing as soon as he is related to a particular distribution. ${ }^{182}$ The problem inherent in this analysis is its lack of specificity, for it could be interpreted to mean that the prohibition is to begin either when the offer is first contemplated or when preliminary agreements are made with underwriters. ${ }^{183}$ It has been suggested that the determinative point in the case of a registered distribution is the time the registration statement is filed, because offers for sales of the distributed security can begin at that time. ${ }^{184}$ However, since the

${ }^{178} 10 \mathrm{~b}-6$ (a) (xi); see note 6 supra.

170 Ibid.

${ }^{180}$ See 3 Loss 1598.

${ }_{181}$ Whitney, Rule 10b-6: The Special Study's Rediscovered Rule, 62 Mrch. L. REv. 567, 577 (1964).

182 See Thomas, Federal Securities Act Handbook 120 (2d ed. 1960).

${ }^{183}$ One practitioner has urged that a shareholder selling a substantial block of securities "should stop purchasing ... when [he has his] first conversation with the underwriter." Remarks of Mr. Lawrence B. Morris, Jr., White \& Case, in Practicing Law Institute, S.E.C. Problems of Controlling Stockholders AND IN UNDERwriting 250 (Israels ed. 1962).

184 See Foshay, supra note 128, at 920-21. The author there notes that the SEC staff does not view the time of filing as determinative of the commencement of the prohibition but rather applies the prohibition to issuers about to distribute securities as well as to those actually involved in a formal distribution. 
underwriting broker-dealer also will be making offers for sales during this period, it is somewhat illogical to permit him to bid and purchase over-the-counter until ten days prior to the effective date of the registration and to restrict the trading of the issuer from the date of filing; presumably both parties share a similar interest in executing a successful offering. A more justifiable point to begin the issuer's prohibition would be one which conforms to the limitations placed upon underwriters. ${ }^{185}$ If the ten-day cushion for over-the-counter purchases has been found to provide sufficient time for the market to adjust after an underwriter's trading, the same period would probably insulate any adverse effects by an issuer's market activities. Finally, a similar analysis suggests that the prohibition upon an issuer's exchange purchases should commence at the same time as the corresponding restriction upon underwriters. ${ }^{188}$

Where several underwriting syndicates are bidding publicly to secure an issue for distribution, rule $10 \mathrm{~b}-6$ (c) (2) (A) provides that the prohibition on market activities begins when the prospective underwriter has agreed to submit or has actually submitted the bid. In practice, however, the agreement to submit a bid sometimes lacks the definiteness assumed by the rule. While a prospective managing underwriter will often send out the underwriting agreement to syndicate members several weeks before the public bidding, provision is usually made to allow an individual underwriter to witldraw from the syndicate within a reasonable time prior to the bidding date. The SEC staff has said that the prohibition of 10b-6 will not become applicable to a syndicate member's activities as long as he retains the right to withdraw, for no legal "agreement" to bid is present. ${ }^{187}$ The staff has further expressed the opinion that, in any case, trading should cease one day before the public bidding date. ${ }^{188}$ This interpretation of the withdrawal provision is undesirable to

${ }^{180}$ See notes 177-81 supra and accompanying text.

${ }^{188}$ See address by Mr. David S. Ruder, November 29, 1966, Northwestern University School of Law, before the Section on Corporate Law Departments of the Illinois State Bar Association. In his speech entitled "Dangers in a Corporation's Purchases of Its Own Shares," Mr. Ruder stated that "the question of when a distribution begins for Rule 10b-6 purposes is not clear. . . . It may even be that the distribution commences for the issuer at the same time that it commences for the underwriter, that is, at the time an underwriter indicates that he will submit a proposal to engage in underwriting the distribution." See p. 5 of Mr. Ruder's prepared remarks.

${ }^{187}$ See Memorandum dated May 23, 1962, in the files of Sullivan \& Cromwell.

${ }^{188}$ Ibid. 
the extent that it may tend to promote schemes to avoid the $10 \mathrm{~b}-6$ restrictions. The present staff position, in effect, encourages members of the underwriting group to include a withdrawal stipulation in their agreement so that trading may be continued until the day before the public bidding. The vice of such a result lies in the fact that the motive behind this addition is not to provide for unforeseen changes in the financial condition of one of the syndicate members, but rather to avoid a legitimately enacted regulation.

The starting point for the prohibition of trading by insiders in the Georgia-Pacific situation varies significantly from the time when limitations are placed upon bidding and purchasing by an issuer in the usual case. This variation probably results from the fact that the actual distribution of shares to the shareholders of the acquired firm may occur weeks or months preceding or subsequent to the crucial valuation date. In future acquisitions by Georgia-Pacific, trading by the defendant insiders is to cease "when an agreement in principle looking towards the acquisition" of another company is reached-"whether or not such agreement is evidenced by a formal contract or agreement."189 Also, there is a ban on trading beginning ten days prior to the date to be used in determining the number of securities to be exchanged.

A practitioner may encounter difficulty in attempting to ascertain when an "agreement in principle" has been reached. It is not clear whether such a standard implies that all of the relevant terms of the bargain have been discussed or merely that the acquiring corporation has assented to the acquisition contingent upon a proffer of acceptable terms. Some clarification is offered in a prospectus which was issued by Genesco, Inc., after a confrontation with the Commission, for that document states that "purchases will be discontinued when a definite arrangement (as opposed to a formal contract) to make the acquisition has been made."100 Yet, the complexities of a corporate acquisition probably prevent isolation of either of the suggested stages of negotiation. Thus, the rule of prudence should guide the corporate insiders to taper off bidding and purchasing as soon as negotiations become sincere and eventually to terminate all market activity in accordance with the intensity of the bargaining.

Termination of the prohibition. The provisions in $10 \mathrm{~b}-6$ gov- 
erning termination of the period of prohibition present an appearance of clarity: an issuer may commence trading activities when the distribution is completed; an underwriter may resume purchasing in the market after his allotment has been distributed and after any stabilizing arrangements or trading restrictions among the underwriters have terminated; any other person may re-enter the market as soon as his allotment has been distributed. ${ }^{191}$ However, because of the inherent vagueness of the term distribution and because of various methods employed by practitioners to accelerate the termination date of the prohibition, these $10 \mathrm{~b}-6$ provisions have required extensive interpretation. For example, the SEC has ruled that a submission by the broker-dealer reporting that the offering has been concluded is not controlling when there are indicia to the contrary. ${ }^{102}$ The Commission has also rejected a de minimus argument by refusing to accept an assertion that the distribution was substantially complete when all but 3,000 shares of a total offering of 290,000 shares had been sold.193 Finally, the general guideline which has been presented is that the distribution will not be viewed as having been completed, and consequently trading cannot be resumed, until all of the securities subject to the distribution have "come to rest in the hands of the investing public."194

The SEC's examination of several different situations has further clarified the delineation of the final termination point. One of the most obviously invalid devices for advancing the termination of the trading prohibition involves use of controlled accounts. A brokerdealer usually attempts this deception by placing securities in a nominal account and later disposing of them in the after-market while

\footnotetext{
101 Rule 10b-6(c) (3); see note 6 supra.

${ }^{102}$ See, e.g., R. A. Holman \& Co., SEC Exchange Act Release No. 7770 (December 15, 1965), aff'd, 366 F.2d 446 (2d Cir. 1966) (shares reported sold were likely to be re.turned); Mayo \& Co., SEC Exchange Act Release No. 7310 (May 8, 1964) (registrant had agreed to repurchase shares reported as sold); Batten \& Co., SEC Exchange Act Release No. 7086 (May 29, 1963), aff'd, 345 F.2d 82 (D.C. Cir. 1964) (registrant retained control over shares reported as having been sold to relatives); C. A. Benson \& Co., SEC Exchange Act Release No. 7044 (March 26, 1963) (shares removed from investment account to trading account within a week after the filing of the termination report).

${ }^{193}$ Shearson, Hammill \& Co., SEC Exchange Act Release No. 7743, at 10 n.20 (November 12,1965$)$.

104 The phrase "comes to rest in the hands of the investing public" was originally used in Oklahoma-Texas Trust, 2 S.E.C. 764, 769 (1937), aff'd, 100 F.2d 888 (10th Cir. 1939), and later reiterated in R. A. Holman \& Co., SEC Exchange Act Release No. 7770 , at 4 (December 15, 1965), aff d, 366 F.2d 446 (2d Cir. 1966); Shearson Hammill \& Co., supra note 193, at 9; Lewisohn Copper Corp., 38 S.E.C. 226, 234 (1958).
} 
continuing to bid so as to maintain or achieve a favorable price level. ${ }^{195}$ A scheme of this sort is in direct violation of $10 \mathrm{~b}-6$ (a) if the broker-dealer has a beneficial interest in the nominal account. On the other hand, factual situations involving sales made subject to contingencies present violations which are less easily recognizable. In this type of case, the purchaser is given the right to return the security if certain events occur. While the Commission has not said categorically that the distribution continues until the sale is confirmed by the purchaser, it has indicated that the contingent sale will be examined ${ }^{196}$-especially in cases where the condition involves a right of rejection after investigation. In order to avoid a finding that the distribution was not completed as reported, the brokerdealer probably should include in his termination report an indication of any questionable firmness in the transactions recorded as sales.

Sales on credit similarly impede the attempt to ascertain with precision the termination point of the $10 \mathrm{~b}-6$ ban on trading. The central issue here is whether a broker-dealer can legitimately resume trading after sales have been made of all the shares which were the subject of the distribution but before payment for those sold on credit has been received. The Commission has taken the position that if there is no indication at the time of the sale or at the time of the termination report that the securities may be returned, the dealer may safely resume trading in the security. ${ }^{107}$ However, when such an indication is present, the SEC places the decisional responsibility upon the brokerdealer: if he has reason to believe that the sales are not firm, he must refrain from trading. Because of the broker-dealer's relationship to his customers, the Commission feels that he is in the better position to evaluate the strength of the purchaser's commitment. ${ }^{198}$ While this

${ }^{105}$ See James H. Price \& Co., SEC Exchange Act Release No. 8052 (April 10, 1967); R. Baruch \& Co., SEC Exchange Act Release No. 7138 (September 11, 1963), supplemented by, SEC Exchange Act Release No. 7932 (August 9, 1966).

${ }^{100}$ See R. A. Holman \&: Co., SEC Exchange Act Release No. 7770, at 4 (December 15, 1965), aff'd, 366 F.2d 446 (2d Cir. 1966).

${ }^{107}$ See testimony of Edward H. Emerson, Special Consultant for the Securities and Exchange Commission, at page 1183 of Official Report of Proceeding before the Securities and Exchange Commission, in Batten \& Co., SEC Exchange Act Release No. 7086 (May 29, 1963), aff'd, 345 F.2d 82 (D.C. Cir. 1964).

${ }^{108} I d$. at 1184 . Another possible guideline for determining the termination point of the period of prohibition may be inferred from the following statement: "Since purchasers of the distributed shares in effect have 7 business days in which to pay, 48 Stat. 891 (1934), 15 U.S.C. §78k(d) (1934); Securities Exchange Act Release No. 4044, Feb. 4, 1948; the underwriter does not know to what extent he may have cancellations 
assumption may have validity in relation to transactions by a small firm or to active accounts in a large firm, the financial status of individuals holding less active accounts with large firms may not be known. Consequently, less should be expected of the dealer in the latter situation. It is significant to note in this regard that the SEC has not affirmatively required that the broker-dealer investigate the exact financial status of his customers; rather, the Commission's position seems only to imply that he must be aware of such matters as the customer's past payment history, his willingness to deal on a cash basis, and the general reliability of his intention to pay for the securities purchased. In any case, whether the indications of questionable firmness are present or not, the broker-dealer is obligated, upon the return of a portion of the offering, to suspend trading and let the market adjust before he attempts to redistribute the shares. ${ }^{100}$

Uncertainty also exists as to the period of the $10 \mathrm{~b}-6$ prohibition with regard to offerings of convertible securities. The difficulty results largely from the SEC's position that when convertible securities are sold subject to a registration statement, the statement will be considered to cover both the securities issued pursuant to the statement and the securities into which they can be converted. ${ }^{200}$ Practitioners have interpreted this assertion to mean that any distribution of convertible securities will continue until all conversion rights have either expired or been exercised.201 Although the Commission has not formally announced its conclusion as to the applicability of $10 \mathrm{~b}-6$ to this type of distribution, a literal application of the rule would prohibit an issuer from bidding for or purchasing either junior or senior securities as long as some conversions could still occur. ${ }^{202}$ Since the issuer has little control over when conversion

until the 7 days have expired. Accordingly out of an abundance of caution, counsel does not regard the distribution as completed until all shares have been paid for." Bloomenthal, The Gase of the Subtle Motive and the Delicate Art-Control and Domination in Over-the-Counter Securities Markets, 1960 Duke L.J. 196, 197 n.2.

108 See testimony cited note 197 supra, at 1186.

200 See Practicing Law Institute, S.E.C. Problems of Controlding Stockholders AND IN UNDERWRITING 40.41 (Israels ed. 1962).

${ }^{201}$ See Buchalter, Purchase by a Corporation of Its Shares: Corporate Cannibalism Without Indigestion, 41 Los ANGeres B. BuLl. 446, 450 n.37 (1966); Address by Mr. David S. Ruder, Northwestern University School of Law, to Section on Corporate Law Departments, Illinois State Bar Association, November 29, 1966.

${ }^{202}$ This extended term for the prohibition apparently would not apply to underwriters or other broker-dealers participating in the distribution, for rule $10 \mathrm{~b}-6$ (c) (3) provides that either of these persons may resume trading when "he has distributcd 
rights will be exercised, the possibility of a lengthy ban on trading is somewhat inequitable. As an alternative to suspension of trading, the issuer may, of course, provide a relatively short period during which conversion would be permitted. However, much of the desirability of convertible securities stems from the fact that a holder of such securities may observe the business in operation before he is forced to make a final decision as to the interest he will hold in it. Consequently, shortening this period of observation would lessen the investor appeal of convertibility.

Under the Georgia-Pacific guidelines, the prohibition period commencing when the acquisition agreement is reached continues until one of the following occurs:

1. In the case of an acquisition requiring a vote of the stockholders of an acquired company, the vote of such stockholders has been consummated,

2. In the case of an acquisition not requiring a vote of the stockholders of an acquired company, the number of shares of stock of G-P has been fixed in accordance with the terms of a binding contract, and

3. In the case of an exchange offer subject to the registration provision of the Securities Act of 1933, such exchange offer has finally been terminated. ${ }^{203}$

Since the SEC requested that similar provisions be included in the Genesco, Inc., prospectus, ${ }^{204}$ these seem to be indicative of guidelines the Commission would propose in similar cases.

\section{EXEMPTIONS}

The absoluteness of the $10 \mathrm{~b}-6$ ban on trading is tempered by specified exemptions. Rule 10b-6 (a) (i) both allows a distributing broker-dealer to make purchases from an issuer other than on a national exchange and exempts transactions between those persons involved in the actual distribution. Generally, this exemption is intended to permit allocation of shares to the syndicate members and to the selling group in preparation for an offering. ${ }^{205}$ Another provision exempts certain unsolicited, privately negotiated purchases. ${ }^{206}$

his participation." An issuer, on the other hand, must wait until the distribution is complete.

203 '64-'66 CCH FED. SEC. L. REP. \91692.

$204 \mathrm{Id}$. at $\$ 77354$.

${ }^{205}$ See 3 Loss 1602 n.145.

${ }^{200}$ Rule 10b-6(a) (ii); see note 6 supra. 
This section is often employed to allow a distributor to acquire securities from a large shareholder in order that he may add them to the securities being distributed. ${ }^{207}$ Under 10b-6 (a) (v) a broker-dealer is allowed to place bids and make purchases pursuant to an unsolicited request to act as a broker. This exemption is justified because the absence of solicitation ensures that he is not raising the market price by active trading. Also, since the bid supposedly did not originate with the broker-dealer, the danger of its being arbitrarily raised is minimized.

The next exemption in $10 \mathrm{~b}-6$ (a) permits offers to sell or the solicitation of offers to buy the securities to be distributed. ${ }^{208}$ By implication, this provision emphasizes that the prohibition of $10 \mathrm{~b}-6$ extends only to bidding and purchasing. Rule 10b-6 (a) (vii) permits any person whose trading would otherwise be prohibited by the rule to exercise any right or conversion privilege he may possess. Also exempted are stabilizing transactions made in accordance with rule $10 \mathrm{~b}-7$ and rights transactions not in violation of rule $10 \mathrm{~b}-8 .{ }^{200}$ The placement of these rules as exemptions from the purview of $10 \mathrm{~b}-6$ reaffirms the latter as a provision presenting a general prohibition. Because $10 \mathrm{~b}-6$ bears this relationship to $10 \mathrm{~b}-7$ or $10 \mathrm{~b}-8$, any violation of these latter rules necessarily involves a violation of $10 \mathrm{~b}-6$.

It is important to note that $10 \mathrm{~b}-6(\mathrm{e})$, adopted as an amendment to $10 \mathrm{~b}-6,{ }^{210}$ exempts employee stock plans insofar as the distribution of the securities to the employees is concerned. This exemption relies heavily upon the definition of employee stock plans in sections $422,{ }^{211} 423,212$ and $424(\mathrm{~b})^{213}$ of the Internal Revenue Code. While $10 \mathrm{~b}-6$ (e) (1) provides that distributions made to employees under a plan which meets the criteria of these sections will not fall within the 10b-6 prohibition, clause (e) (2) exempts a plan which provides for periodic payments and purchases by employees or their agent. Because of the general terms of $10 \mathrm{~b}-6$ (e) (2) and the consequential ease with which a plan may qualify under them, that clause

${ }^{207}$ See 3 Loss 1602 n.146. Exemption clauses (iii) and (iv), which are for rather specialized application, are self-explanatory. See note 6 supra.

${ }^{208}$ Rule 10b-6 (a) (vi); see note 6 supra.

${ }^{200}$ Rule 10b-6 (a) (viii); rule 10b-6 (a) (ix); see note 6 supra.

${ }^{210}$ See SEC Exchange Act Release No. 5208 (August 15, 1955); SEC Exchange Act Release No. 5199 (July 19, 1955).

${ }^{211}$ INT. REV. CODE OF 1954, $\$ 422$.

212 INT. REv. CODE OF 1954, § 423.

${ }^{213}$ INT. REV. CODE OF 1954, § 424 (b). 
probably encompasses most types of plans not meeting the criteria established by the Internal Revenue Code.

Rule 10b-6 (f) provides for exemptions to be given by the SEC on an ad hoc basis. ${ }^{214}$ In the original enactment of this provision, the SEG declared that the section was meant "to provide for unusual situations which may fall within the literal language of a rule but [which] can be demonstrated not to be comprehended within its purpose."215 The original expectation of the Commission was that the exemptive power would "be available only on rare occasions."216 However, some generalization can be made as to the various circumstances under which the power is exercised. For example, when an employee stock plan desired to buy a portion of the shares which its company was distributing, an exemption was allowed.217 Also, as noted above, the Commission will often exempt purchases on a foreign exchange made by a foreign underwriter who is undertaking the offering of a security registered under the Securities Act in connection with a broker-dealer in the United States. ${ }^{218}$ Finally, exemptions from the trading prohibition have been granted in several cases to dealers soliciting securities for non-underwritten exchanges of stock between large insurance companies. ${ }^{219}$

\section{CoNCLUSION}

As an attempt to preserve an undistorted market during the course of a distribution, 10b-6 has definite value. The rule has proved useful as a weapon with which the SEC can attack obviously manipulative activities which inject an artificial character into the market at the time of an offering. Furthermore, precedent makes fairly clear the general categories of activities to be avoided by the broker-dealer or issuer who legitimately desires to continue bidding and purchasing

\footnotetext{
214 See note 6 supra. The authority to grant exemptions has heen vested in the Director of the Division of Trading and Markets. SEC Exchange Act Release No. 7873 (April 27, 1966).

${ }_{215}$ SEC Exchange Act Release No. 5194 (July 5, 1955), reprinted at 20 Fed. Reg. 5075 (1955).

210 Ibid.

${ }^{217}$ See the Genesco, Inc. Prospectus of May 10, 1966, portions of which are reprinted in '64-'66 CGH FED. SEC. L. REP. T 77354.

${ }^{218}$ See Memorandum on Application of SEC Rules 10b-6, 10b-7 and 10b-8 to Foreign Offerings, February 7, 1966, in the files of Sullivan \& Cromwell; note 175 supra and accompanying text.

${ }^{210}$ See Foshay, Market Activities of Participants in Securities Distributions, $45 \mathrm{VA}$. L. REv. 907, 931-33 (1959).
} 
as long as permissible. However, in relation to many matters, the published interpretations of the rule present inadequate guidelines for the individual seeking to conform to the rule's limitations. While other meaningful interpretations are issued in private "no action" letters, some matters, such as the applicability of the term distribution to unregistered secondary distributions and the precise point at which the prohibition on trading by issuers commences, appear to require clarification. Until such clarifications are made, the extent to which rule 10b-6 achieves the purpose behind its promulgation will be limited. 